\title{
Strophomenid brachiopods from the Rhenish Lower Devonian (Germany)
}

\author{
ULRICH JANSEN
}

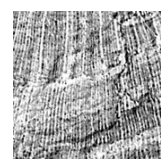

\begin{abstract}
Early Devonian Strophomenida (Brachiopoda) from the Rhenish Slate Mountains (Germany) are described. Three genera are introduced as new: Gigastropheodonta [type species: Leptaena (Strophomena) gigas McCoy, 1852], Rhenostropheodonta (type species: $R$. rhenana gen. nov. et sp. nov.) and Gibbodouvillina (type species: Strophomena taeniolata G. \& F. Sandberger, 1856). The diagnosis of the poorly known genus Boucotstrophia Jahnke, 1981 (type species: Stropheodonta herculea Drevermann, 1904) is revised. These and several further taxa are briefly discussed with regard to phylogenetic relationships, palaeobiogeographical implications, palaeobiological aspects and stratigraphical significance. $\bullet$ Key words: Brachiopoda, Strophomenida, Devonian, Rhenish Slate Mountains, taxonomy, biostratigraphy, palaeobiology, palaeobiogeography.
\end{abstract}

JANSEN, U. 2014. Strophomenid brachiopods from the Rhenish Lower Devonian (Germany). Bulletin of Geosciences 89(1), 113-136 (7 figures, 1 table). Czech Geological Survey, Prague, ISSN XXX. Manuscript received April 22, 2013, accepted in revised form July 19, 2013, published online December 17, 2013; issued January 21, 2014.

Ulrich Jansen, Senckenberg Forschungsinstitut und Naturmuseum, Paläozoologie III, Senckenberganlage 25, D-60325 Frankfurt am Main, Germany; Ulrich.Jansen@senckenberg.de

The Early Devonian Strophomenida from the Rhenish Slate Mountains (Rheinisches Schiefergebirge, Germany) have been paid little attention to since the classical works of d'Archiac \& de Verneuil (1842), G. \& F. Sandberger (1856) or Drevermann $(1902,1904)$. A few taxa have been studied more recently by Jahnke (1971, 1981, 1986). In the frame of a large monograph on the "stropheodontoid" Strophomenida, Harper \& Boucot (1978a-c) revised all genera of this large group on a world-wide scale from the Ordovician to the Devonian. They introduced the genus Fascistropheodonta and the subgenus Leptostrophia (Leptostrophiella) basing these on Rhenish type species, and they redescribed the Rhenish taxa Douvillinella and Plicostropheodonta. Besides, several Rhenish species were assigned by these workers to genera established in regions outside the Rhenish Slate Mountains and partly from different stratigraphic levels, as well.

The present author started his work on Rhenish "stropheodontoids" in the early nineties (Jansen 1994, 1998a, b) focusing on materials from the classical localities Seifen (upper part of Middle Siegenian, Westerwald) and Oberstadtfeld (upper part of Lower Emsian, Eifel area). The study of the Seifen fauna in particular has shown that intense collecting and detailed analysis of these multi-species allochthonous assemblages are necessary to record the complete morphology of each taxon. Even the trivial ques- tion which ventral and dorsal valves belong to the same species was not easy to answer in some cases. With regard to the genus Boucotstrophia Jahnke, 1981, common in the Seifen fauna, the author has come to the conclusion that its type species B. herculea (Drevermann, 1904) was often taxonomically united with or mistaken for the similar-sized but unrelated "Stropheodonta" gigas (McCoy, 1852) which occurs in the same fauna. In the opinion of the present author, the genus Boucotstrophia has largely been misunderstood by previous workers starting with its original diagnosis (Jahnke 1981) and in the following years, for example by García-Alcalde (1992), Aït-Malek et al. (2000) and in the revised Treatise on Invertebrate Palaeontology, Part H (Cocks \& Rong 2000). It was necessary to revise the genus and to erect a new genus for the group of "S." gigas.

Another group of Rhenish strophomenids is represented by Strophomena piligera G. \& F. Sandberger, 1856. The species has been reported from various stratigraphic levels within the Emsian of Europe and was assigned by Harper \& Boucot (1978c, p. 34) to Strophodonta Hall, 1850 whose type-species Strophomena demissa Conrad, 1842 comes from the Middle Devonian Hamilton Group in E North America. Three years later, Jahnke (1981, pp. 152, 153) assigned $S$. piligera to the Rhenish genus Plicostropheodonta Sokolskaya, 1960. The actual revision has shown that the taxon piligera actually includes at least two Rhenish species belonging to a new genus. 


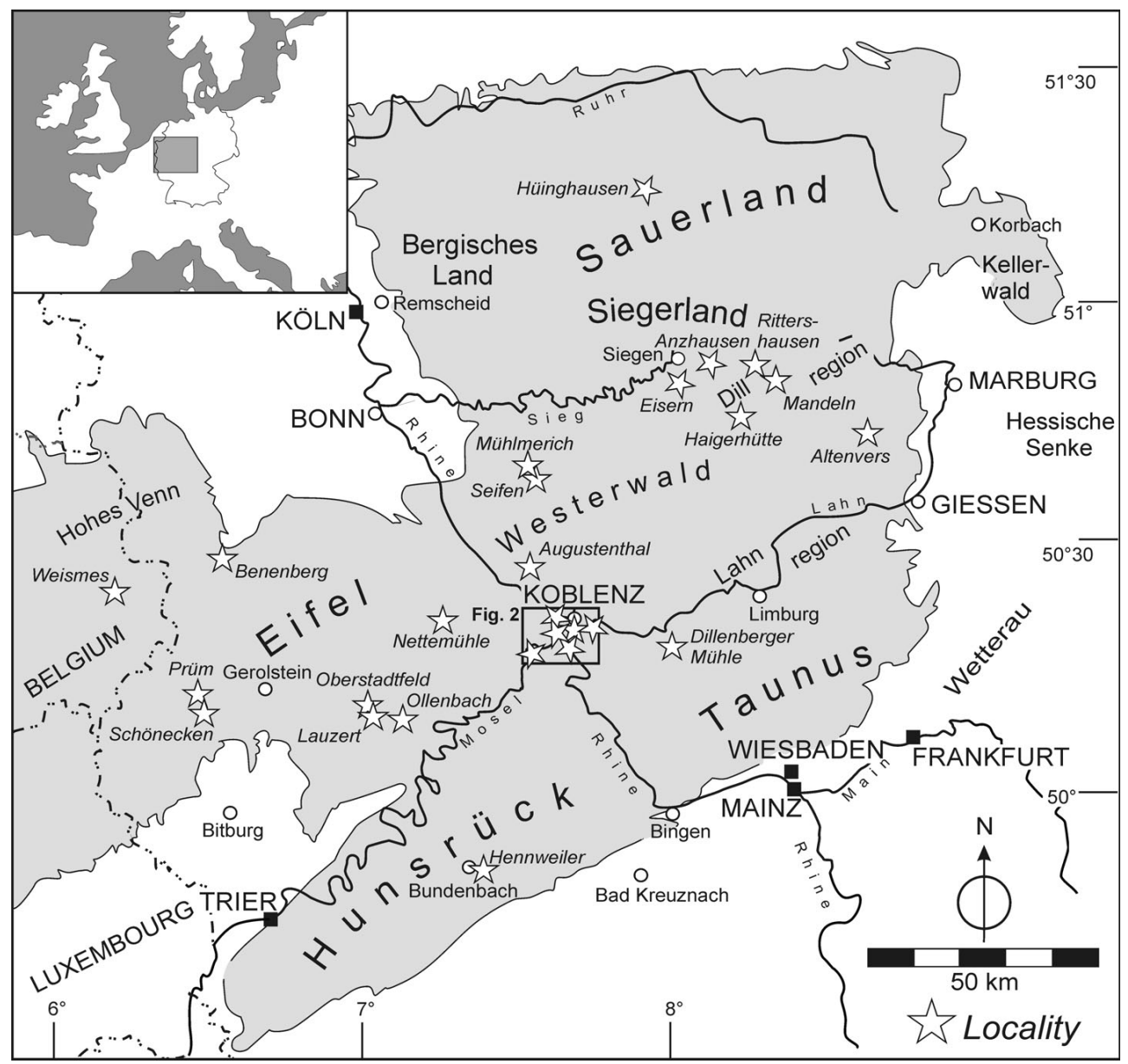

Figure 1. Sketch map showing strophomenid localities in the Rhenish Slate Mountains (shaded in grey), Germany. The position of the map in Fig. 2 is indicated.

Finally, the poorly known Rhenish species Strophomena taeniolata G. \& F. Sandberger, 1856 is revised. Rösler (1954) examined this species and determined it as a representative of Strophodonta Hall, 1850. At that time, Strophodonta was still a comprehensive genus with very wide scope. Later, Jahnke (1971) assigned it to the Bohemian genus Bojodouvillina Havlíček, 1967, and Harper \& Boucot (1978b) finally included it in their new genus Protodouvillina, which is based on a type species from the Hamilton Group, again. Jahnke (1981, p. 157) determined Protodouvillina taeniolata in the Armorican Massif and García-Alcalde (1992, fig. 4) in the Cantabrian Mountains. The present author has compared the Rhenish forms with the presumable congenerics from North America to elucidate their relationships. It turned out unavoidable to introduce a new genus for the species taeniolata and related forms.

The classical regional stratigraphy, including the stages Siegenian and Emsian in German sense, is used herein (Carls 1987, Jansen 2001) because the global GSSP subdivision still cannot be reproduced with satisfying precision in these siliciclastic-neritic, rhenotypic successions. In spite of this restriction, the strophomenids turned out to be excellent biostratigraphic markers on a regional scale. For the position of the lithostratigraphic units as used in the present work the Devonian Correlation Tables (Weddige 1996, 1998a, b, 2000) and the "Stratigraphic Table of Germany" (German Stratigraphic Commission 2002) may be consulted.

This work represents a part of a monographic revision of the rhynchonelliformean brachiopod taxa from the Rhenish Lower Devonian, with the intention to improve the knowledge on their morphology, to reconstruct their phylogenetic relationships, to clarify their stratigraphic ranges and to get new insights in their palaeobiology and palaeobiogeography.

\section{Material and methods}

The materials studied are preserved as internal and external moulds of mainly disarticulated shells, rarely of articulated ones. Latex casts were made to examine the external and internal shell morphologies. The specimens were coated with magnesium oxide prior to photographing. They are largely stored in the Senckenberg Forschungsinstitut und Naturmuseum Frankfurt am Main (Senckenberg Museum), but in other museums/institutions in Europe and overseas, as well. 


\section{Localities}

The localities are situated in different regions of the Rhenish Slate Mountains (Figs 1, 2) and further specified in the lists of materials.

\section{Abbreviations}

The lists of materials contain abbreviations used both for singular and plural: AVIM - internal mould of articulated valves; DVEM - external mould of dorsal valve; DVIM internal mould of dorsal valve; DVIM+EM - internal mould of dorsal valve with corresponding external mould (counterpart); VVIM - internal mould of ventral valve; VVEM - external mould of ventral valve; VVIM+EM - internal mould of ventral valve with corresponding external mould (counterpart).

\section{Institutional abbreviations}

IPB - Paläontologisches Institut Bonn; MB.B. - Museum für Naturkunde, Berlin, brachiopod collection; MW - Museum Wiesbaden, G. \& F. Sandberger collection; SMF Senckenberg Museum, Frankfurt am Main; SMF-Mbg. former collection of the Institut für Geologie und Paläontologie, University of Marburg a.d. Lahn, today stored in the Senckenberg Museum, Frankfurt am Main; USNM - Smithsonian, United States National Museum of Natural History, Washington D.C., USA; YPM - Peabody Museum of Natural History, Yale University, New Haven/Ct., USA.

\section{Morphological terminology}

The terminology used in the systematic part largely follows the Treatise on Invertebrate Paleontology, Part H (Williams et al. 1997, Williams \& Brunton 1997, Cocks \& Rong 2000). Some additional terms and terms used in a slightly different sense shall be explained:

Capilla (pl. capillae; adj. capillate). - Micro-costella, very fine radial rib on outer surface of shell, reaching a maximum width of hardly more than $0.15 \mathrm{~mm}$.

Cavities for accomodation of brachiophores and cardinal process lobes. - Pairs of cavities in the apical region of the ventral valve in which the cardinal process lobes and the brachiophores of the dorsal valve fit in articulated shells. They represent a subdivision of the central apical cavity and are medially separated by the ventral process. These structures obviously have an articulatory function. The cavities for the cardinal process lobe and the brachiophore of

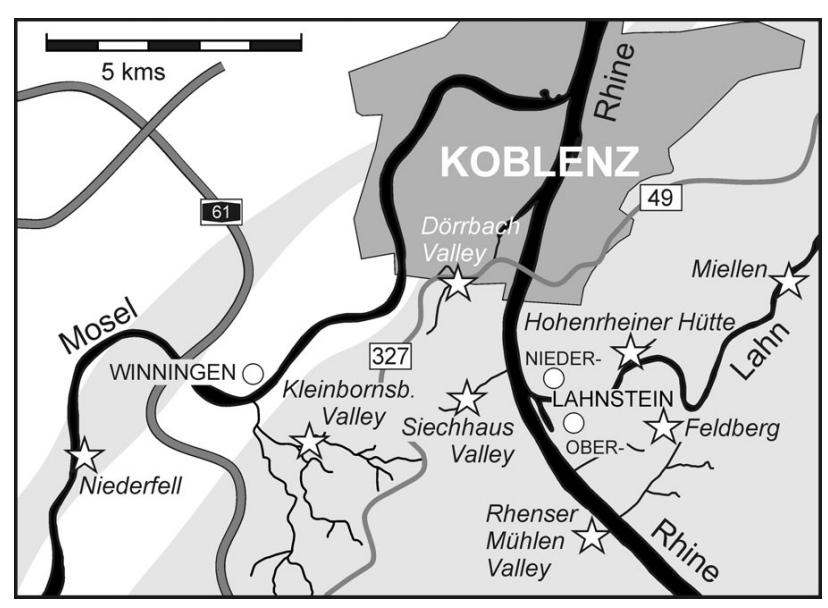

Figure 2. Strophomenid localities in the central Rhenish Slate Mountains around Koblenz (Upper Emsian outcrops shaded in grey).

each side are either separated by a ridge as in Gigastropheodonta (Fig. 4K) or Rhenostropheodonta (Fig. 5J) [note that the cavities are preserved as ridges and the separating ridge is represented by a furrow on the internal moulds figured], or they are not separated as in Boucotstrophia (Fig. 3K). A taxonomic significance is ascribed to this difference. The term "crural fossette" has been used to describe cavities receiving the posteroventral edge of the brachiophore or crural plate (Williams \& Brunton 1997), but this term refers to cavities in the hinge teeth.

Interstriate. - Parvicostellate ornamentation consisting of relatively coarser costellae clearly separating groups of more or less numerous, uniform capillae (for example in Gibbodouvillina: Fig. 5D) or very fine costellae in a very regular pattern (= "interstriat" sensu Paeckelmann \& Sieverts 1932, p. 41; = “interstriée" sensu Jahnke 1981, p. 149; Jahnke 1986, pp. 108-110; Aït-Malek et al. 2000, pp. 311, $312,315)$. The coarser costellae may arise from capillae in a distance from the apex. The clear term "interstriate" is used for this characteristic type of ornamentation, a specification of the "unequally parvicostellate" type (Harper \& Boucot 1978a, p. 58) which can be traced back to Williams (1953) (some workers just use the term "parvicostellate" instead). The latter term is regarded here as more general, also including ornamentations with costellae of different size but no distinct interstriate pattern.

Medial septa. - Pair of septa starting from notothyrial platform or starting within dorsal adductor field and may extend anterior to it, close to median plane, may be developed as low ridges (for example in Gibbodouvillina: Fig. 5B).

Paradental plates (= minute struts sensu Harper \& Boucot 1978a). - Pair of plates located lateral to the ventral 
cavities for accomodation of cardinal process lobes, leaving slits at the internal mould, resembling dental plates but may have evolved independently (for example in Gibbodouvillina: Fig. 5A).

Side septa (different from the use in Cocks \& Rong 2000).Pair of septa or ridges, located anterior or anterolateral to dorsal adductor scars, located more lateral than medial septa and may be continuous with dorsal muscle-bounding ridges (for example in Rhenostropheodonta: Fig. 5N).

\section{Systematic palaeontology}

Order Strophomenida Öpik, 1934

Superfamily Strophomenoidea King, 1846

Family Amphistrophiidae Harper, 1973

Subfamily Mesodouvillininae Harper \& Boucot, 1978b

Discussion. - Representatives of the subfamily Mesodouvillininae are very common in Early Gedinnian ( early Lochkovian) deposits of the Ebbe Anticlinorium, where internal and external moulds of concavo-convex shells of Mesodouvillina triculta (Fuchs, 1919) cover bedding surfaces in the Flaserschiefer Member of the Hüinghausen Formation. The marine succession is interrupted after the Early Gedinnian and returns with a transgression in the Middle Siegenian so that the Late Gedinnian and Early Siegenian evolution of the subfamily must have taken place outside the Rhenish shelf. In contrast to previous views (Jahnke 1981; Cocks \& Rong 2000), the Middle to Late Siegenian genus Boucotstrophia Jahnke, 1981 is regarded here as a member of the Mesodouvillininae, as well. Mclearnites cherguiensis Jansen, 2001 from the approximately coeval Merzâ-Akhsaï Formation (Dra Plains, S Anti-Atlas, Morocco), for example, is morphologically close to Boucotstrophia herculea but differs in the absence of a geniculate profile. The morphology of the ventral and dorsal apical regions and muscle fields are generally considered as the most important and stable characters indicating the mesodouvillinine affinity, whereas the shell profiles may have changed more rapidly in the course of evolution. The Early Emsian genus Pseudoleptostrophia Gad, 1997 belongs to the same family, but should be included in the subfamily Amphistrophiinae according to its resupinate profile.

\section{Genus Boucotstrophia Jahnke, 1981}

Type species. - Stropheodonta herculea Drevermann, 1904, p. 276.

Revised diagnosis. - Shells very large, gently to moderately concavo-convex in profile and becoming dorsally ge- niculate along the commissural margin. Ornamentation variable, finely costellate, varying from subuniformly costellate to unequally parvicostellate and partly interstriate with two or three finer costellae intercalated between coarser costellae. Hinge line denticulate for about 3/4 to all of its length. Ventral process strongly developed, pyramidal, flanked by a pair of deep cavities for the reception of the cardinal process lobes, cavities for the brachiophores united with these. Ventral muscle field large, impressed, semielliptical to subtriangular in outline, laterally enclosed by distinct muscle-bounding ridges which are more or less curved convexly outward and commonly continued as weak ridges along anterior margin of muscle field. Ventral diductor scars moderately flabellate, separated by median myophragm. Cardinal process bilobed, laterally flanked by moderately long, widely divergent brachiophores, which are clearly separated from the cardinal process. Dorsal muscle platform absent; paired adductor scars faintly to moderately impressed, separated by median ridge and delimited laterally by low muscle-bounding ridges convexly curved outwards; side and medial septa lacking or poorly developed in large specimens; breviseptum present, relatively long.

Species included. - Only the type species Stropheodonta herculea Drevermann, 1904.

Discussion. - The revision of Boucotstrophia is based on the study of internal and external moulds of ventral and dorsal valves and a few moulds of articulated valves of its type species $B$. herculea (Drevermann, 1904) mainly from the Seifen Formation (Middle Siegenian, Westerwald), its stratum typicum. Drevermann (1904) knew the ventral morphology of his species well, and he distinguished the latter from the co-occurring, similar-sized species "Stropheodonta" gigas McCoy, 1852, but he had no dorsal valves of herculea for study. The scrutiny of Drevermann's materials and new, excellently preserved material has confirmed the presence of two different species which finally turned out to be representatives of two different genera: Boucotstrophia and Gigastropheodonta gen. nov.

In the course of their revision of the "Stropheodontacea", Harper \& Boucot (1978a-c) studied specimens of both taxa mentioned. The re-examination of their specimens in the Smithsonian (Washington D.C.) by the present author has shown that internal moulds of ventral valves of Boucotstrophia herculea (1978b, pl. 31, figs 1, 3, 6) and ventral and dorsal valves of "Stropheodonta" gigas (1978b, p. 31, figs 2, 4, 7; 1978c, pl. 36, figs 1-3) from the Seifen fauna were assigned to "Rhenostrophia cf. $s u b$ arachnoidea (d'Archiac \& de Verneuil, 1842)" whereas internal moulds of dorsal valves of B. herculea (1978a, pl. 4, figs 8, 10-12, pl. 5, figs 1, 3, 5) were determined as "Leptostrophia (Rhytistrophia) sp.". The accompanying 
ventral valve which Harper \& Boucot assigned to the latter taxon (1978a, pl. 3, fig. 4, pl. 4, fig. 11) belongs to Leptstrophiella explanata (Sowerby, 1842), supported by the presence of "true" dorsal valves of this species in the same fauna (Jansen, in prep.). Rhenostrophia Boucot, 1960 (type species: Orthis subarachnoidea, d'Archiac \& de Verneuil, 1842) was treated as a nomen dubium under the Strophomenoidea by Cocks \& Rong (2000). In my opinion, the type species of this genus may represent a taxon of the order Orthotetida.

New problems started with the erection of the genus Boucotstrophia, because its original diagnosis was obviously based not only on its type species "Stropheodonta" herculea Drevermann, 1904, but on the group of "Stropheodonta" gigas McCoy, 1852 (Gigastropheodonta gen. nov.), as well (Jahnke 1981, p. 150). As a result, the original diagnosis contains joint characters of the ventral valves of Boucotstrophia and Gigastropheodonta, such as the large and impressed muscle field, but includes also characters of the dorsal valve only developed in the latter genus, such as reduced "socket plates"and elevated muscle platform. Unfortunately, Jahnke's new species “Boucotstrophia" minor, which he erected in the same work, has to be assigned to Gigastropheodonta in accordance to the diagnostic characters of this genus, and the same applies further taxa previously assigned to Boucotstrophia, as well (García-Alcalde 1992, Aït-Malek et al. 2000). In my opinion, all described species of Boucotstrophia except for its type species belong to Gigastropheodonta. In the revised edition of the Treatise on Invertebrate Palaeontology, Part $H$, Cocks \& Rong (2000) figured a ventral valve of $B$. herculea (fig. 187/1b) and a dorsal valve of G. gigas (fig. 187/1a) - both determined as "B. herculea". An attempt is made herein to clarify the confusion concerning the genus Boucotstrophia and the species which, in my opinion, had erroneously been related to it.

The internal morphology of Boucotstrophia is clearly of the mesodouvillinine type, resembling that of advanced Devonian representatives of Mclearnites or Mesodouvillina (see, for example, Renouf 1972, Harper \& Boucot 1978b or Jansen 2001). These genera and Boucotstrophia have the general morphology of the ventral and dorsal apical characters and muscle fields in common: cavities for accomodation of cardinal process lobes and brachiophores not clearly separated by ridges (as it is the case in Gigastropheodonta); ventral diductor scars faintly or moderately impressed and more or less subdivided by radial ridges; brachiophores long, clearly separated from cardinal process and widely divergent; elevated dorsal muscle platform lacking, medial and side septa lacking or poorly developed.

Finally, Jahnke (1981) has included Boucotstrophia in a new subfamily Megastrophiinae. The different morphology of the Middle Devonian Megastrophia Caster, 1939 precludes a closer relationship that would justify this; the latter genus is characterized by a commonly interstriate ornamentation, strongly subdivided ventral diductor fields and the presence of an elevated dorsal muscle platform and side septa.

Comparison. - Boucotstrophia differs from the widely distributed genus Mesodouvillina Williams, 1950 (type species: Stropheodonta subinterstrialis seretensis Kozłowski, 1929) in much larger, dorsally geniculate shells with subuniformly costellate to unequally parvicostellate or partly interstriate ornamentation, whereas the latter has concavoconvex shells showing a predominantly interstriate ornamentation. Boucotstrophia further differs in the presence of flabellate ventral diductor scars, contrasting with the faintly subdivided diductor scars in Mesodouvillina. Boucotstrophia differs from Mclearnites Caster, 1945 (type species: Brachyprion mertoni McLearn, 1924) mainly in larger and dorsally geniculate shells. Silurian to Lochkovian species show a smooth or faintly subdivided ventral diductor field whereas the large Siegenian and Emsian representatives show strong radial ridges giving the diductor field a flabellate aspect ( $c f$. Jansen 2001). Probably, the first Boucotstrophia evolved from one of these during the Early Siegenian and migrated into the Rhenish Sea with the beginning of the Middle Siegenian. Boucotstrophia is distinguished from Geniculomclearnites Harper \& Boucot, 1978b [type species: Mclearnites (Geniculomclearnites) genicularia Harper \& Boucot, 1978b] by larger shells and flabellate diductor scars which are not subdivided in the second genus; a Cantabrian species of Geniculomclearnites shows the presence of a strong peripheral ridge in the dorsal valve (cf. García-Alcalde 1992) which is absent in Boucotstrophia. Boucotstrophia differs from Sinostrophia Hamada, 1971 (type species: S. kondoi Hamada, 1971) from NE China in dorsally geniculate shells, finer ornamentation, stronger cardinal process, longer brachiophores and curved dorsal muscle-bounding ridges; Sinostrophia shows straight and diverging dorsal muscle-bounding ridges. The shell profile of Boucotstrophia contrasts with the resupinate profile of the Rhenish genus Pseudoleptostrophia Gad, 1997 (type species: Leptostrophia dahmeri Rösler, 1954) which in addition lacks a breviseptum in the dorsal valve and shows a uniformly costellate ornamentation. It is unknown whether Pseudoleptostrophia developed from an amphistrophiine ancestor or attained the resupinate profile independently.

\section{Boucotstrophia herculea (Drevermann, 1904)} Figure 3A-K

v*1904 Stropheodonta herculea nom. n. Drevermann, pp. 276, 277, pl. 32, figs 5, 5a, b, 6. 
v p 1978a Leptostrophia (Rhytistrophia) sp. - Harper \& Boucot, pl. 4, figs 8, 10, 12, pl. 5, figs 1, 3, 5; non pl. 3, fig. 4, pl. 4, fig. 11 (= Leptostrophiella explanata, early form).

v p 1978b Rhenostrophia cf. subarachnoidea (d'Archiac \& de Verneuil, 1842). - Harper \& Boucot, pl. 31, figs 1, 3, 6; non figs 2, 4, 7 (= Gigastropheodonta gigas), non fig. 5 (G. cf. gigas).

v p 2000 Boucotstrophia herculea. - Cocks \& Rong, p. 294, fig. 187/1b; non fig. 187/1a, 1c (= Gigastropheodonta gigas).

v 2003 Boucotstrophia herculea. - Poschmann \& Jansen, pl. 2, fig. 6.

Lectotype. - Internal mould of ventral valve and corresponding external mould, SMF-Mbg. 2354, figured by Drevermann (1904, pl. 32, figs 5, 5a, 5b) and selected here as lectotype (Fig. 3A-C). Dimensions of the internal mould: L $68 \mathrm{~mm}, \mathrm{~W} \sim 61.5 \mathrm{~mm}$.

Type stratum and locality. - Seifen Formation, upper part of Middle Siegen Group, Middle Siegenian (middle Lower Devonian); locality Seifen, Westerwald, Rhenish Slate Mountains, Germany. Topographical Mapsheet of Rheinland-Pfalz 1:25,000, No. 5311 Altenkirchen.

Material. - Seifen Formation, Middle Siegenian, Westerwald. Seifen, near Dierdorf, classical localities, $~ 830 \mathrm{~m} \mathrm{SE}$ of railway station (see Dahmer 1934); different collectors, e.g., F. Drevermann, J. Hefter, T. Henn: 3 VVIM+EM [lectotype SMF-Mbg. 2354; SMF 66682, 66685], 1 AVIM+DVEM [MB.B. 153], 1 AVIM [MB.B. 158.1-2], 13 VVIM [SMF 66677-66681, 66687, 85221, 93633, 93636, 94835, 94836; SMF-Mbg. 5137; YPM 13835], 1 VVEM [YPM 601401]. Seifen; leg. A. Vogel: 1 VVIM [SMF 85222]. Niederähren, railroad cut, $200 \mathrm{~m} \mathrm{~W}$ of church at Niederähren near Seifen; leg. A. J. Boucot: 3 VVIM [USNM 220650, 220652, 220654), 4 DVIM [USNM 220473, 220474, 220476, 220477]. Ascheid near Seifen; leg. E. Grebel: 3 VVIM [SMF 66697, 93637, 93638]. Haberscheid, abandoned quarry near road from Seifen to Puderbach: 5 VVIM [SMF 94830-94834, leg. P. Carls], 1 DVIM+EM [SMF 85674, leg. U. Jansen], 2 DVIM [SMF 94837, leg. U. Jansen; SMF 94999, leg. P. Carls]. Mühlmerich near Eichen, large quarry; leg.
E. Grebel: 10 VVIM [SMF 66686, 66689-66695, 85220, 94829], 2 DVIM [SMF 85671, 85673]. - Middle Siegenian, Westerwald. Augustenthal Formation, Augustenthal near Neuwied, quarry opposite the factory; leg. J. Hefter: 2 VVIM [SMF 66688, 93634]. - Middle Siegenian, Siegerland. Eisernhardt Fm., Ahöhe near Eisern: 1 AVIM [MB.B. 3624]. - Upper Siegenian, Siegerland. Upper Siegen Group, Anzhausen, railway cut opposite the mill; leg. P. Dienst: 1 VVIM [MB.B. 3149]. - Upper Siegenian, Eifel region. Saxler? Fm., Ollenbach-Üssbach, $250 \mathrm{~m} \mathrm{~S}$ of junction of the two creeks; leg. S. Simpson: 1 VVIM [SMF 93635]. Upper Siegen Group, "Untere Dunkle Schichten", Nette-Mühle, $0.5 \mathrm{~km} \mathrm{NW}$ of the mill, along the road to Ettingen; leg. S. Simpson: 1 VVIM+EM [SMF 93639]. - Siegenian, Hunsrück. Taunusquarzit Group, Hennweiler near Kirn: 1 VVIM plus fragments of VVEM [SMF 66696].

Diagnosis. - As for the genus.

Remarks. - The species is common in Middle Siegenian deposits of the Siegerland, Westerwald, Eifel and Hunsrück, but generally rare in Late Siegenian deposits. Its geographic distribution outside the Rhenish Slate Mountains remains unclear. Maillieux (1936) described the species from the Middle Siegenian "Quartzophyllades de Longlier" in the Ardennes (Belgium), but did not illustrate it. Godefroid et al. (1994, fig. 10) reported it from different formations of the S flank of the Dinant Synclinorium (Ardennes, Belgium). Jahnke \& Racheboeuf (1980, pp. 203, 204, fig. 53, pl. 27, figs 5-7) described a few poorly preserved specimens of Boucotstrophia sp. from the Siegenian "Schistes et Calcaires de l'Armorique" of the Armorican Massif (France) whose characters suggest a close affinity to $B$. herculea. Further reports of Boucotstrophia from the Siegenian of Spain, from the Celtiberian Chains, the Sierra de Guadarrama and the Cantabrian Mountains (Carls 1987, Carls \& Valenzuela-Ríos 1998) are still to be verified with the material. Boucotstrophia herculea resembles Mclearnites cherguiensis Jansen, 2001 from the Middle or Late Siegenian Merzâ-Akhsaï Formation in the Dra Plains (S Anti-Atlas, Morocco) but the Rhenish species differs by a dorsally geniculate profile, slightly different, more unequally parvicostellate ornamentation and the presence of a breviseptum in the dorsal valve; $M$. cherguiensis has a plano-convex profile with faintly convex,

Figure 3. Boucotstrophia herculea (Drevermann, 1904). All figures at natural size (× 1.0), unless otherwise indicated. Seifen Formation, Middle Siegenian (middle Lower Devonian), all localities near Seifen, Westerwald, Rhenish Slate Mountains, Germany. • A-C - SMF-Mbg. 2354, lectotype, Drevermann collection. Internal mould of ventral valve (A), silicon cast of corresponding external mould (B) and detail view ( $\times 2.1)$ of the latter to show the ornamentation (C). Locality: "Seifen". • D, E-SMF 94999. Internal mould of dorsal valve (D) and latex cast (E). Locality: Seifen, Haberscheid; leg. P. Carls. $\bullet$ F-H - SMF 85673. Internal mould of dorsal valve (F), latex cast $(\mathrm{G})$ and cardinalia, enlarged $(\times 2.3)$ posterior view $(\mathrm{H})$. Locality: Mühlmerich near Eichen. • I - SMF 85671. Internal mould of dorsal valve. Locality: Mühlmerich near Eichen; leg. E. Grebel. • J, K - SMF-Mbg. 5137. Internal mould of ventral valve $(\mathrm{J})$, slightly enlarged $(\times 1.5)$ posterior view of apical area $(\mathrm{K})$. Locality: "Seifen". 


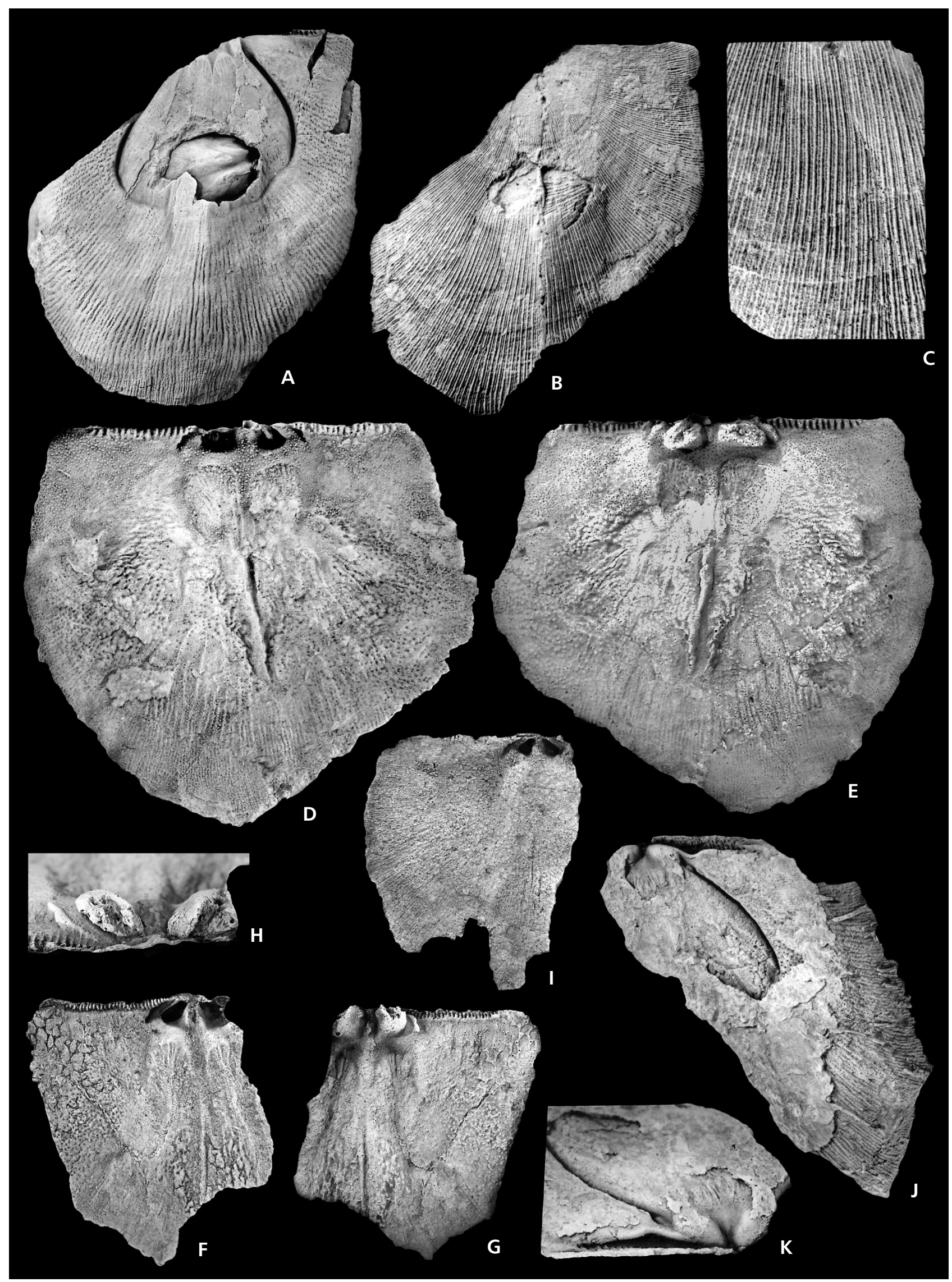


non-geniculate ventral valve and a uniformly costellate ornamentation; in addition, the ventral muscle-bounding ridges are less convexly curved.

\section{Family Strophodontidae Caster, 1939}

Discussion. - The family Strophodontidae is represented in the Rhenish Slate Mountains by at least four genera: Gigastropheodonta gen. nov. [type species: Leptaena (Strophomena) gigas McCoy, 1852], Fascistropheodonta Harper \& Boucot, 1978c (type species: Orthis Sedgwicki d'Archiac \& de Verneuil, 1842), Plicostropheodonta Sokolskaya, 1960 (type species: Orthis Murchisoni d'Archiac \& de Verneuil, 1842) and Rhenostropheodonta gen. nov. (type species: $R h$. rhenana gen. nov. et sp. nov.).

The erection of the new genus Gigastropheodonta results from the exclusion of the Middle Siegenian to Late Emsian group of Leptaena (Strophomena) gigas McCoy, 1852 from Boucotstrophia.

Fascistropheodonta is characterized by the presence of a sharply fasciculate ribbing superimposed on capillae or fine costellae. It includes its type species $F$. sedgwicki (d'Archiac \& de Verneuil, 1842) (Fig. 6M) and F. rudis (Kegel, 1913), both occurring in the Middle and Upper Siegenian substages. In the Late Emsian Wiltz Formation (Eifel region), a third, still undescribed species with relatively low plications occurs (Harper \& Boucot 1978c, p. 25 , pl. 45, figs $4,5,7,8$, pl. 46, figs 1, 3-5). The Siegenian-Emsian genus Plicostropheodonta is mainly represented by its type species $P$. murchisoni (Fig. 6K, L) and $P$. virgata (Drevermann, 1902) (Fig. 6J). The genus is characterized by the presence of a strongly plicate macroornamentation superimposed on capillae or fine costellae; the strong plications are commonly visible on internal moulds, as well. The dorsal interior shows an elevated muscle platform. The two species have chiefly been distinguished by simple versus increasing plications. There are further, almost unknown or poorly known Early Devonian taxa from Central and Western Europe to be considered in the frame of a revision of the two genera which share a comparable plicate plus capillate ornamentation, for example Leptaena sarthacensis Oehlert \& Davoust, 1879, L. acutiplicata Oehlert \& Davoust, 1879, Stropheodonta (?) diffusa Oehlert, 1896, St. fascigera Drevermann, 1902, St. steiningeri Drevermann, 1907 and St. furcillistria Fuchs, 1915. In my opinion, the taxonomic value of the macro-ornamentation, the number of plications and the pattern of their numerical increase, has been overemphazised in previous works, and more attention should be paid to internal characters; the intraspecific variability of the macro-ornamentation is probably higher than hitherto assumed. In the Seifen and Stadtfeld faunas, specimens with varying number and strength of plications and widely varying tendency of bifurcation and insertion cooccur. A more comprehensive material would be necessary to establish a sound taxonomy of these forms.

Finally, there is the group of forms represented by Strophomena piligera G. \& F. Sandberger, 1856 and related species. It had been assigned either to Strophodonta or Plicostropheodonta by previous workers, and it is now regarded as a new genus Rhenostropheodonta herein. It is internally similar to Plicostropheodonta, but lacks a plicate macro-ornamentation.

\section{Genus Gigastropheodonta gen. nov.}

Etymology. - From Greek gigas (substantive from mythology, very large folk), referring to the large size of shells and the name of the type species, combination with the classical genus name Stropheodonta; nomenclatory gender: feminine.

Type species. - Leptaena (Strophomena) gigas McCoy, 1852 , p. 386.

Diagnosis. - Shells of large to very large size, with strongly concavo-convex to dorsally geniculate profile; ornamentation variable, ranging from slightly unequally parvicostellate to distinctly interstriate, more rarely subuniformly costellate; style of ornamentation may change on a single valve; weak tendency to produce low rounded plications may be present; hinge line partly to entirely denticulate. Ventral process small, often excavated by variously developed median depression, commonly with furrow or tubular chamber in its anterior face; ventral cavities for accomodation of cardinal process lobes and brachiophores separated by a ridge on each side; ventral muscle field large, bilobed, strongly impressed, enclosed by strong muscle-bounding ridges; adductor and diductor scars clearly differentiated; adductor scars dendritic, separated by median furrow; diductor scars strongly subdivided by numerous radial ridges, flabellate. Cardinal process lobes strong, with attachment faces posteroventrally or posteriorly directed; brachiophores very short, located at the base of the cardinal process; dorsal adductor field subelliptical to subrectangular in outline, moderately elevated on muscle platform; short central breviseptum and pair of faint side septa present. Bulbous subperipheral ridge may be variously developed in the interior of both valves.

Species included. - Leptaena (Strophomena) gigas McCoy, 1852, Boucotstrophia minor Jahnke, 1981, Boucotstrophia velica García-Alcalde, 1992, Boucotstrophia jahnkei Aït-Malek, Racheboeuf \& Lazreq, 2000. Further undescribed forms, possibly new species, are known to the author from the Dra Plains (S Anti-Atlas, Morocco) and the Rhenish Slate Mountains. 
Table 1. Comparison of the co-occurring species Boucotstrophia herculea (Drevermann, 1904) and Gigastropheodonta gigas (McCoy, 1852).

\begin{tabular}{|c|c|c|}
\hline Character & Boucotstrophia herculea & Gigastropheodonta gigas \\
\hline outline & commonly brachythyrid & megathyrid, often faintly mucronate \\
\hline ornamentation & $\begin{array}{l}\text { unequally parvicostellate to uniformly costellate, partly } \\
\text { tending to become interstriate }\end{array}$ & $\begin{array}{l}\text { variable, largely interstriate, partly uniformly } \\
\text { costellate }\end{array}$ \\
\hline cavities accomodating brachiophores & united with cavities for cardinal process lobes & $\begin{array}{l}\text { clearly separated from cavities for cardinal } \\
\text { process lobes }\end{array}$ \\
\hline tubular chamber in ventral process & absent & commonly present \\
\hline ventral muscle field & moderately impressed, moderately flabellate & $\begin{array}{l}\text { strongly impressed, diductor scars subdivided } \\
\text { by numerous ridges, strongly flabellate }\end{array}$ \\
\hline ventral muscle-bounding ridges & $\begin{array}{l}\text { sharply delimited, commonly narrow or moderately } \\
\text { thick }\end{array}$ & often indistinctly delimited, very thick \\
\hline brachiophores & moderately long, separated from cardinal process lobes & short, closely adjacent to cardinal process lobes \\
\hline dorsal muscle platform & absent & present \\
\hline dorsal muscle-bounding ridges & absent or low & present \\
\hline
\end{tabular}

Comparison. - The combination of following characters of Gigastropheodonta indicates its affiliation to the family Strophodontidae: strongly concavo-convex to dorsally geniculate profile, strongly impressed ventral muscle field with strongly subdivided ventral diductor scars, elevated dorsal muscle platform and presence of dorsal side septa. The new genus is distinguishable from the mesodouvillinine Boucotstrophia Jahnke, 1981 mainly by a generally more convex or geniculate ventral valve, often longer trail, interstriate or predominantly interstriate ornamentation, ventral cavities for accomodation of cardinal process lobes separated by ridges from those for the brachiophores, more impressed ventral muscle field with more strongly subdivided diductor scars, shorter brachiophores less diverging from cardinal process lobes, elevated dorsal muscle platform, shorter dorsal breviseptum and the presence of distinct side septa (see above, under Boucotstrophia and Table 1).

Gigastropheodonta is distinguished from Rhenostropheodonta gen. nov. by larger shells and a dorsal breviseptum lacking anteriorly a prong. Rhenostropheodonta is like a smaller-sized sister genus of Gigastropheodonta sharing many characters with it, for example the apical morphology and muscle fields of the ventral and dorsal valves. Gigastropheodonta is distinguished by larger and essentially non-plicate shells from the strongly plicate Plicostropheodonta Sokolskaya, 1960. The same is to be stated in the comparison with Fascistropheodonta Harper \& Boucot, 1978c (type species: Orthis Sedgwicki d'Archiac \& de Verneuil, 1842) furthermore showing a multiplicate macro-ornamentation arranged in a fasciculate pattern superimposed on capillae or fine costellae (Fig. 6M); the ventral muscle field is generally less impressed in representatives of that genus, and the brachiophores are longer with respect to the cardinal process lobes. Gigastropheodonta is similar to Megastrophia Caster, 1939 [type species: Strophomena (Stropheodonta) concava Hall, 1857] and seems at first sight to be related to that genus (specimens studied: USNM 14104a; 14516; 116374a, b, f; 124365, 173987; 205147a-e; 220695-220697). Gigastropheodonta differs in more distinctly geniculate shell, more impressed ventral muscle field delimited by stronger muscle-bounding ridges, the presence of separate cavities for the accomodation of cardinal process lobes and brachiophores, different orientation of cardinal process lobes with attachment faces directed posteroventrally or posteriorly, short brachiophores closely adjacent to the cardinal process and subelliptical to subrectangular outline of the dorsal adductor field.

Ventral valves of the Middle Devonian type species of Megastrophia, M. concava from the Appalachians (E North America), tend to attain a rounded, almost hemispherical shape; the costellae separating the intercalated capillae are more pronounced than in most representatives of Gigastropheodonta. In the dorsal valve, the cardinal process surpasses the hinge line posteriorly, and the attachment faces for the diductor muscles are directed in posterior to posterodorsal direction; the brachiophores are longer, clearly separated from the cardinal process lobes, widely divergent and located far more lateral along the cardinal margin. The dorsal adductor field tapers anteriorly, and the individual posterolateral adductor scars tend to attain a subtriangular outline. Considering this combination of characters Megastrophia appears as a remote relative of the Rhenish genus.

\section{Gigastropheodonta gigas (McCoy, 1852)} Figure 4A-L

V* 1852 Leptaena (Strophomena) gigas McCoy, p. 386, pl. 2, fig. 7.

v p? 1865 Streptorhynchus gigas. - Davidson, p. 83, pl. 16, figs 1,3 , non fig. 2 ?

p 1893 Strophomena protaeniolata Maurer. - Maurer, pp. 5, 6, pl. 2, figs 1, 3, non fig. 2 .

v 1904 Stropheodonta gigas. - Drevermann, pp. 273-275, pl. 32, figs $1-4$. 
cf 1935 Stropheodonta gigas. - Mauz, p. 76.

v 1960 Stropheodonta gigas. - Paproth, table 1, pl. 2, figs 3, 4.

v p 1978b Rhenostrophia cf. subarachnoidea (d'Archiac \& de Verneuil, 1842). - Harper \& Boucot, pl. 31, figs 2, 4, 7 , non figs 1, 3, 6 (= Boucotstrophia herculea), 5 (sp. nov.? aff. G. gigas).

v 1978c Rhenostrophia cf. subarachnoidea (d'Archiac \& de Verneuil, 1842). - Harper \& Boucot, pl. 36, figs 1, 3, fig. 2 ?

pv p 2000 B. [Boucotstrophia] herculea (Drevermann). - Cocks \& Rong, p. 294, fig. 187/1a, c, non fig. 1 b (= Boucotstrophia herculea).

v 2003 "Stropheodonta" gigas. - Poschmann \& Jansen, pl. 2, fig. 4.

Lectotype. - The specimen figured by McCoy (1852, pl. 2, fig. 7), designated by Mauz (1935, p. 76: “Typus"); a poorly preserved, strongly flattened external mould of a dorsal valve showing in parts an interstriate ornamentation (McCoy's figure is strongly idealized); stored under the number H 3883 in the Sedgwick Museum (Cambridge, U.K.). Dimensions: $\mathrm{L}=83 \mathrm{~mm}, \mathrm{~W}=72 \mathrm{~mm}$. The fauna from Looe includes internal moulds of ventral valves as well (Davidson 1865; restudied by the present author in the Natural History Museum London) which are closely resembling the Rhenish specimens so that the conspecificity appears sufficiently verified.

Type stratum and locality. - Strata of Siegenian age at Looe, Cornwall, SW England.

Material. - Seifen Fm., Middle Siegenian, Westerwald. Seifen, near Dierdorf, classical localities, $830 \mathrm{~m} \mathrm{SE}$ of railway station (see Dahmer 1934), different collectors, e.g., F. Drevermann, J. Hefter: 10 VVIM [SMF-Mbg. 2353; SMF 66998, 85315, 85327-85330, 85333, 93778, 93779], 1 DVIM+EM [SMF-Mbg. 2352], 4 DVIM [SMF 85327, 85335; replicas YPM 13835 (2)]. Ascheid near Seifen; leg. E. Grebel: 4 VVIM [SMF 85311, 85316-85318]. Niederähren near Seifen; leg. A. J. Boucot (USNM) and E. Dörr, A. Keuerleber \& R. Werner (SMF) (2 slightly different localities): 6 VVIM [SMF 85309, 85323; USNM 220651, 220653, 220655, 220659], 1 DVIM [USNM 220657]. Haberscheid near Seifen: 2 VVIM [SMF 85308, leg. P. Carls; SMF 85310, leg. U. Jansen]. Mühlmerich near Eichen; leg. J. Hefter, E. Grebel: 6 VVIM [SMF 85314, 85319, 85321, 93780, 93781, 93783], 3 DVIM [SMF 85307, 85322, 85337], 1 DVIM+EM [SMF 93784]. - Siegenian, Siegerland. Middle Siegen Group, Dillberg near Eisern: 1 VVIM [SMF 85334]. Langenholdinghausen: 1 VVIM [SMF 85326]. - Middle Siegenian, Westerwald. Willroth; leg. R. Seibert: 1 DVIM+EM [SMF 85306]. G. cf. gigas from the Augustenthal Fm., Augustenthal; leg. J. Hefter: 7 VVIM [SMF 85302, 85303, 85325, 93774-93777], 6 DVEM [SMF 85301, 85304, 85305, 85324, 93773, 93782].

Diagnosis. - Shells of large to very large size, with wide hinge line, some specimens with short ears, with strongly concavo-convex to geniculate profile; trail shorter than visceral disk, trail of dorsal valve sharply delimited from visceral disk; ornamentation very fine, slightly unequally parvicostellate to distinctly interstriate with groups of a variable number of capillae separated by slightly coarser costellae, partly subuniformly capillate, and pattern of ornamentation may change on the same valve. Hinge line denticulate for $1 / 2$ to $3 / 4$ to all of its width; 17 to 27 denticles on each side of the delthyrium. Ventral process variously developed, commonly with tubular chamber in its anterior face. Ventral muscle field very large, subelliptical to oval in outline; adductor scars commonly more or less elevated, rarely not elevated; thick muscle-bounding ridges present. Elevated dorsal muscle platform present, with moderately developed brevisepum and faint side septa. Subperipheral ridge more or less developed in the interior of ventral valve; dorsal visceral disk relatively flat.

Comparison and discussion. - The species is presently known from the Middle and Upper Siegenian of the Rhenish Slate Mountains, the Ardennes and South England. Gigastropheodonta gigas has frequently been confused with the often co-occurring mesodouvillinine species Boucotstrophia herculea (Drevermann, 1904). Apart from a similar size, internal moulds of these two species are rather dissimilar, whereas isolated and fragmentary external moulds can be difficult to assign to the one or the other species (comparison: see above and Table 1). A second Rhenish species of Gigastropheodonta occurs in the Lower Emsian; it is smaller, shows a less pronounced geniculation and a different ventral adductor field;

Figure 4. Gigastropheodonta gigas (McCoy, 1852). All figures at natural size (× 1.0), unless otherwise indicated. Seifen Formation, Middle Siegenian (middle Lower Devonian), all localities near Seifen, Westerwald, Rhenish Slate Mountains, Germany. • A-F-SMF-Mbg. 2352, Drevermann collection. Internal mould of dorsal valve $(\mathrm{A})$, silicon cast of internal mould $(\mathrm{B})$, enlarged $(\times 3.0)$ posterior view of cardinalia, latex cast $(\mathrm{C})$, corresponding external mould (D) and lateral view of it (E), latex cast of external mould, detail $(\times 2.7)$ of ornamentation (F). Locality: "Seifen". • G, H - SMF 85337. Internal mould of dorsal valve $(\mathrm{G})$ and latex cast of it $(\mathrm{H})$. Locality: Mühlmerich near Eichen; leg. J. Hefter. $\bullet$ I-K - SMF 85323. Latex cast of internal mould of ventral valve (I), internal mould (J) and enlarged $(\times 1.6)$ oblique posterior view of it $(\mathrm{K})$. Locality: Seifen, Niederähren; leg. R. Werner. $\bullet$ L - SMF 93778 . Internal mould of ventral valve. Locality: Seifen, new road; leg. J. Hefter. 


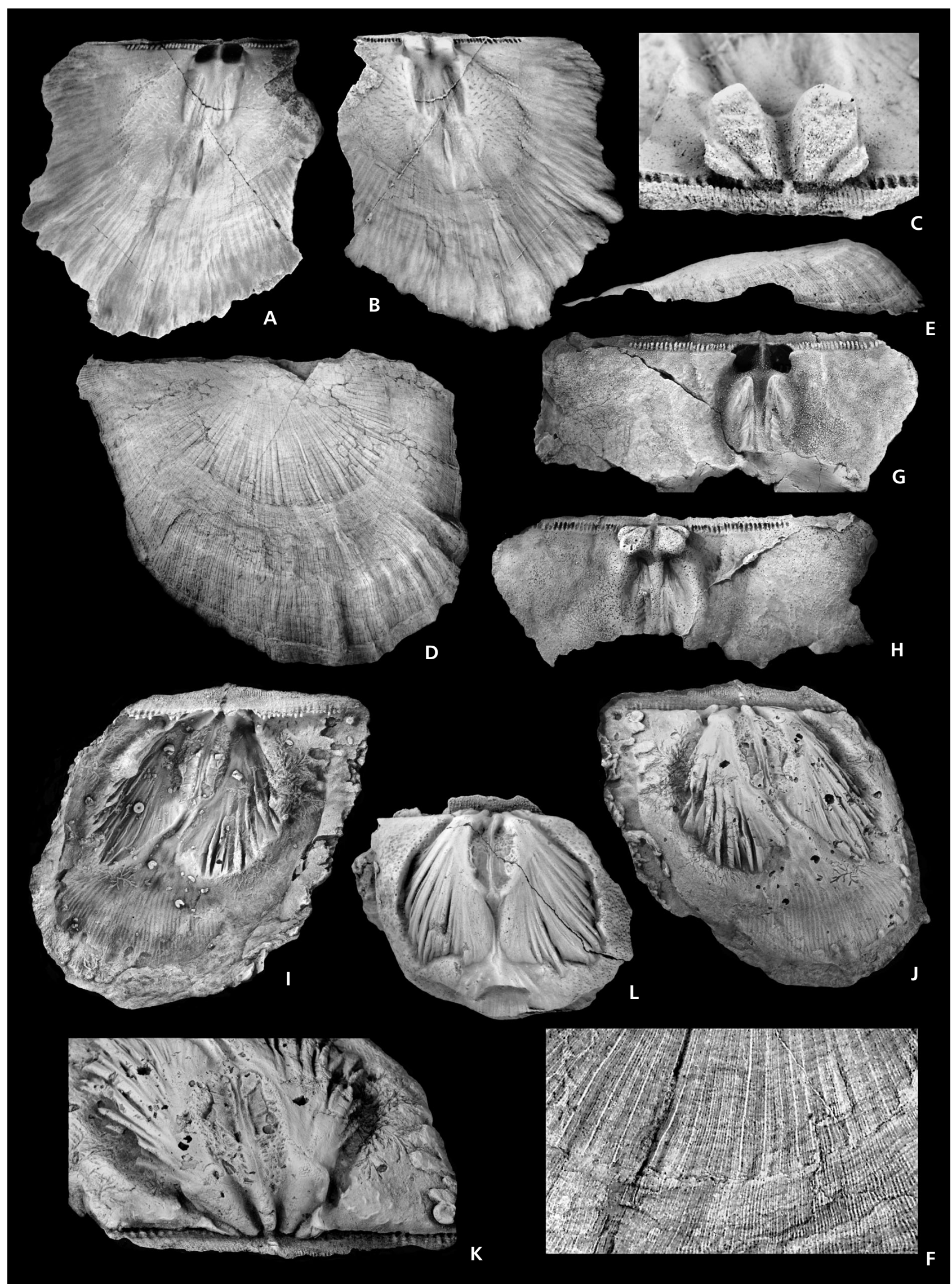


the genus further extends into the Upper Emsian (Jansen, in prep.).

Gigastropheodonta gigas differs from G. minor (Jahnke, 1981) from the Emsian Marettes Formation of the Armorican Massif in larger size and a shorter trail; the trail can be very long and recurved in the French species. In the ventral valve, the adductor scars are elevated in G. gigas, whereas only the anterior adductor scars are elevated in G. minor. The Rhenish species is distinguished by larger shells and the presence of a less constantly interstriate, partly almost uniformly capillate ornamentation from G. velica (García-Alcalde, 1992) which occurs in the Emsian La Ladrona Formation of the Cantabrian Mountains (Santa María del Mar section, Asturias, N Spain). The Spanish species shows relatively coarser costellae separating the groups of capillae. Gigastropheodonta gigas differs from G. jahnkei (Aït-Malek, Racheboeuf \& Lazreq, 2000) from the upper part of the Mdâouer-el-Kbîr Formation (lowermost Upper Emsian) of the Dra Plains (S Anti-Atlas, Morocco) by much larger shells and relatively wider hinge line with 17 to 27 denticles per flank; the number of denticles reaches only 17 per flank in the Moroccan species; the ventral muscle field of the Rhenish species tends to be more subelliptical or suboval in outline - in contrast to a subtriangular muscle field in G. jahnkei (confirmed by examination of own topo- and stratotypic material).

\section{Genus Rhenostropheodonta gen. nov.}

Etymology. - From Latin rhenus (noun) [= Rhine river], combination with the classical genus name Stropheodonta; nomenclatory gender: feminine.

Type species. - Rhenostropheodonta rhenana gen. nov. et sp. nov.

Species included. - Rhenostropheodonta rhenana gen. nov. et sp. nov., Strophomena piligera G. \& F. Sandberger, 1856.

Diagnosis. - Shells of medium to large size, with markedly concavo-convex to geniculate profile; ornamentation finely and unequally parvicostellate, more or less distinctly interstriate; weak tendency to produce low plications may be present; hinge line entirely denticulate. Ventral process small, mostly excavated by median furrow, tubular chamber or pit in its anterior face; ventral muscle field large, more or less bilobed, strongly impressed, enclosed by weak but mostly distinct muscle-bounding ridges; adductor scars separated by median furrow; diductor scars strongly flabellate. Cardinal process lobes strong, ventrally oriented and with posteriorly directed diductor attachment faces; brachiophores very short, laterally adjacent to cardinal pro- cess lobes; dorsal adductor field on slightly elevated muscle platform; central breviseptum present, commonly bearing an anterior prong, flanked by a pair of low side septa. Subperipheral ridge usually present in ventral and dorsal valves.

Comparison. - Rhenostropheodonta gen. nov. differs from Plicostropheodonta Sokolskaya, 1960 in the absence of coarse plications. Differences from Gigastropheodonta gen. nov. are discussed above. Rhenostropheodonta is distinguished from Strophodonta Hall, 1850 (type species: Strophomena demissa Conrad, 1842) from North America mainly by the finer and commonly interstriate ornamentation, the presence of distinct ventral muscle-bounding ridges, a ventrally directed cardinal process and brachiophores more closely adjacent to the cardinal process. Strophodonta is characterized by a relatively coarse, uniformly costellate ornamentation and posteriorly directed cardinal process accompanied by brachiophores situated more laterally. The study of specimens of the type species Str. demissa has confirmed these differences (AMNH 42306; SMF 31674-31676). Rhenostropheodonta is distinguished from Asturistrophia García-Alcalde, 1992 (type species: Ast. insolita García-Alcalde, 1992) from the Emsian of N Spain by the interstriate ornamentation, stronger and more continuous ventral muscle-bounding ridges and shorter brachiophores closely adjacent to the cardinal process lobes; in contrast, the Spanish genus has a uniformly costellate ornamentation, the ventral muscle-bounding ridges are only posterolaterally developed or lacking, and the brachiophores are long and more protruding in anterolateral direction. The other genera assigned to the family Strophodontidae by Cocks \& Rong (2000) are very different from Rhenostropheodonta.

\section{Rhenostropheodonta rhenana gen. nov. et sp. nov.} Figure 5G-N

1897 Strophomena (Strophodonta) piligera Sandb. Frech, pl. 24b, fig. 5.

v 1969 Strophodonta piligera. - Werner, pl. 2, fig. 2.

p 2013 Plicostropheodonta piligera. - Schemm-Gregory \& Henriques, p. 28 above, p. 28 below? (male), p. 29 below, p. 30 below?, p. 31 below, p. 32?; non p. 29 above (different ornamentation, ?Iridistrophia sp.); non p. 30 above, p. 31 above (= Iridistrophia sp.).

Etymology. - From Latin, rhenanus, - $a$, -um (adj.) [= Rhenish, relating to the Rhine river].

Holotype. - Internal mould of ventral valve (SMF 66712), leg. F. Drevermann, Fig. 5I-L. Dimensions: L = 29 mm, $\mathrm{W}=35 \mathrm{~mm}$. 
Type stratum and locality. - Hohenrhein Formation, beds with Brachyspirifer ignoratus (Maurer, 1883), Lahnstein Group, lower part of Upper Emsian (upper Lower Devonian). Miellen/Lahn river, near Bad Ems, Rhenish Slate Mountains, Germany.

Material. - Upper Emsian, central Middle Rhine, lower Lahn and lower Mosel regions. Hohenrhein Fm., Miellen, valley of Lahn river, different collectors, e.g., leg. F. Drevermann, T. Henn, O. Follmann, G. Solle: 7 VVIM+EM [SMF 93668-93671, 93692-93694], 106 VVIM [holotype SMF 66712; SMF 93648 (15), 93649 (2), 93654, 93657, 93658, 93659 (20), 93660-93663, 93664 (4), 93667, 93676-93679, 93680 (12), 93681 (2), 93682 (13), 93683 (4), 93694, 93695 (15), 93696, 93699; MB.B. 3165; YPM 601388, 601395], 2 VVEM [SMF 93666, 93702], 3 DVIM+EM [SMF 93690, 93691, 93704]. 21 DVIM [SMF 93653 (5), 93655, 93656 (6), 93665-93667, 93687 (4), 93696, 93697], 40 DVEM [SMF 93648 (4), 93649 (2), 93654 (2), 93657 (3), 93664 (3), 93684 (2), 93685 (5), 93686 (12), 93695 (2), 93697, 93698 (2), 93703; YPM 601389]. Lower part of Hohenrhein Fm., Kleinborns Valley near Koblenz, Koblenzer Stadtwald; leg. J. Hefter, U. Jansen (slightly diff. locs): 1 VVIM+EM [SMF 93711], 13 VVIM [SMF 66714, 85290, 93706 (10), 93710], 1 VVEM [SMF 66716], 1 DVIM+EM [SMF 93709], 2 DVIM [SMF 93708 (2)], 1 DVEM [SMF 93707]. Hohenrhein Fm., Hohenrheiner Hütte near Lahnstein; leg. O. Follmann: 1 DVIM+EM [MB.B. 3163.1]. Hohenrhein Fm., Feldberg near Oberlahnstein; leg. Schwerd: 1 AVIM [MB.B. 3204.1]. Emsquarzit Fm., Rhenser Mühlen Valley at Rhens/river Rhine: 2 VVIM [SMF 66715 (2); leg. O. Follmann], 1 DVIM [SMF 66713; leg. U. Jansen]. Siechhaus Valley, near Koblenz: 1 VVIM [YPM 236696; Krantz collection], 1 DVIM+EM [cf. $R$. rhenana; SMF 93705a+b; leg. J. Hefter], 2 DVEM [SMF 93712 (2)]. "Oberlahnstein": 2 VVIM [YPM 236700, 236701]. - Upper Emsian, Prüm Syncline, Eifel region. Wiltz Fm., foot of Hartberg near Prüm, W flank of road from Niederprüm to Ellwerath, $580 \mathrm{~m} \mathrm{SW}$ of TP $540.5 \mathrm{~m}$; leg. R. Werner: 3 VVIM [SMF 25677 (3)], 1 DVEM [SMF 25677].

Diagnosis. - Shells of medium to large size; profile of ventral valve moderately to strongly convex, ratio width to length of ventral internal moulds between 1.1 and 1.3. Ornamentation more or less distinctly interstriate, with a variable number of capillae between the costellae. Number of denticles along hinge line 22 to 40 per flank. Ventral process commonly with thin median furrow in its anterior face, rarely with deep tubular chamber. Ventral muscle field large, transversely suboval or subrhombical in outline, occupying a great portion of visceral disk; posterolateral limitations diverging at an angle of generally more than $90^{\circ}$; median ridge between diductor scars commonly narrow.
Comparison and discussion. - Rhenostropheodonta rhenana differs from the classical Rhenish species $R$. piligera (G. \& F. Sandberger, 1856) (Fig. 5O, P) by on average larger shells, a more convex ventral valve with a slightly higher ratio width to length of commonly 1.1 to 1.3 of ventral internal moulds contrasting with 1.0 to 1.2 in $R$. piligera, 22 to 40 denticles per flank versus only ca 20 in $R$. piligera, the presence of a mostly thin median furrow in the ventral process contrasting with a deep median pit or tubular chamber in $R$. piligera, larger and broader ventral muscle field which is transversely suboval or subrhombical and not distinctly bilobed in outline, narrower median ridge separating the diductor scars medianly. The posterolateral limitations of the ventral muscle field diverge at a wider angle of more than $90^{\circ}$, whereas this angle is commonly below this value in $R$. piligera.

Many specimens hitherto been determined as $R$. piligera in collections actually belong to the new species. Rhenostropheodonta rhenana has its onset in the Emsquarzit Formation (basal part of Upper Emsian) and becomes most abundant in the overlying Hohenrhein Formation - it is restricted to early Late Emsian strata (Lahnstein Group) and represents a very common component of many faunas, whereas $R$. piligera is less common and mainly occurs in the middle Late Emsian Laubach Group, but may have its first occurrence in the uppermost beds of the Hohenrhein Formation. Rhenostropheodonta piligera probably evolved from $R$. rhenana in the latest "Lahnstein time".

Family Douvillinidae Caster, 1939

Subfamily Protodouvillininae Harper \& Boucot, 1978b

Discussion. - The Rhenish Protodouvillininae occur mainly in deposits of Emsian age. The Early Emsian species Crinistrophia elegans (Drevermann, 1902) (Fig. 6H, I) is characterized by a plano-convex profile and strong dorsal medial septa curved convexly outwards (Jahnke 1971). It is abundant in the Stadtfeld Formation, but possibly conspecific specimens have rarely been found in the Spitznack Formation of the Taunus, as well. The species has been synonymized with Crinistrophia crinita Havlíček, 1967 from the Zlíchovian of Bohemia (Jahnke 1971), but this seems to be doubtful. The late Late Emsian species Douvillinella filifer (Schmidt, 1914) (Fig. 6C, D) has a resupinate ventral valve, different shape of ventral muscle field and less developed dorsal septa (Jahnke 1981).

In the present work, the classical species "Protodouvillina" taeniolata (G. \& F. Sandberger, 1856) is reviewed and included in the new genus Gibbodouvillina. The Middle Devonian "Protodouvillina" interstrialis (Phillips, 1841) represents a second species of this genus to be considered. The generic affiliation of the possible 
protodouvillinine "Stropheodonta" umbonata Dahmer, 1951 from the Köbbinghausen Formation (Př́dolian, Remscheid Anticlinorium) is still to be clarified. The Rhenish Protodouvillininae occur in subtypes of the rhenotypic facies indicating relatively offshore, open-shelf palaeoenvironments with highly diverse faunal assemblages.

\section{Genus Gibbodouvillina gen. nov.}

Etymology. - From Latin gibbus (noun) [= strong convexity, hump], alluding to the convex shape of the ventral valve; combination with the classical genus name Douvillina; nomenclatory gender: feminine.

Type species. - Strophomena taeniolata G. \& F. Sandberger, 1856 , p. 360.

Diagnosis. - Shells of moderate to large size, semielliptical in outline, with moderately or strongly concavo-convex to geniculate profile; ornamentation interstriate. Paradental plates present; ventral muscle field semielliptical or piriform to rounded subtriangular in outline, completely bisected by narrow median ridge, laterally enclosed by sharply individualised, high muscle-bounding ridges which are convexly curved outwards; the latter are very low and thin or absent anterior to the muscle field; adductor scars anteromedially enclosed by diductor scars; diductor scars largely smooth. Brachiophores moderately long and widely diverging, clearly separated from cardinal process; dorsal adductor field impressed, bisected by low median ridge starting from notothyrial platform; dorsal muscle-bounding ridges poorly developed; thin breviseptum may be present; medial septa low and thin, tuberculate, long and straight, diverging at an acute angle to another, starting posteriorly from median ridge between adductor scars.

Species included. - Strophomena taeniolata G. \& F. Sandberger, 1856, Orthis interstrialis Phillips, 1841. Further undescribed forms, apparently new species, are known to the author from the Emsian of the Dra Plains (S Anti-Atlas, Morocco) and the W Pyrenees (N Spain).
Discussion and comparison. - Gibbodouvillina gen. nov. is externally similar to the type genus of the subfamily, Protodouvillina Harper \& Boucot, 1978b (type species: Strophomena inaequistriata Conrad, 1842), to which representatives of Gibbodouvillina have commonly been assigned so far. The new genus differs from Protodouvillina by the presence of distinct paradental plates, semielliptical or piriform to rounded-subtriangular ventral muscle field with diductor scars enclosing adductor scars anteriorly, narrow median ridge bisecting the muscle field and much lower, straight medial septa in the dorsal valve. Specimens of the type species Protodouvillina inaequistriata (Conrad, 1842) from the Middle Devonian Hamilton Group of the E United States have been studied for comparison (USNM 220608-220610, 220616, 220618, 220619; Harper \& Boucot 1978b: pl. 25, figs 7-11, pl. 26, figs 3-7). The species differs in a ventral muscle field with subrectangular outline and diductor scars which do not enclose the adductor scars anteriorly; instead, an elevated boss may separate the diductor scars there. Paradental plates are commonly lacking in Protodouvillina, and the medial septa in the dorsal valve are much higher and commonly curved convexly outwards. The cardinal process of Gibbodouvillina is still too insufficiently known to be compared with that of Protodouvillina. A single dorsal valve of $G$. taeniolata is available; it shows a small, posteriorly directed, bilobed cardinal process (Fig. 5B).

Gibbodouvillina has probably evolved from a species of Mesodouvillina Williams, 1950 by the development of a strongly concavo-convex to geniculate profile. The new genus may represent a transitional stage between Mesodouvillina and Protodouvillina. The present author saw numerous specimens of Gibbodouvillina from different areas of Central and Western Europe and North Africa which clearly show the diagnostic characters seemingly not affected by much intraspecific variation.

Gibbodouvillina differs from Bojodouvillina Havlíček, 1967 (type species: Leptaena phillipsii Barrande, 1848; Pragian in original sense to Zlíchovian, Bohemia) in stronger and sharper, continuous ventral muscle-bounding ridges, less impressed ventral muscle field which is semielliptical or piriform to rounded subtriangular in outline,

Figure 5. Strophomenid brachiopods from the Upper Emsian (upper Lower Devonian) of the central Rhenish Slate Mountains, Germany. All figures slightly enlarged (× 1.5), unless otherwise indicated. • A-F - Gibbodouvillina taeniolata (G. \& F. Sandberger, 1856); Sandberger collection; locality: Niederlahnstein, Middle Rhine region; A - MW 289c/54.10.01, paralectotype; internal mould of ventral valve; B, C - MW 289a/54.10.02, paralectotype; latex cast of internal mould of dorsal valve (B) and internal mould (C); D - MW 289e/54.10.04, paralectotype, latex cast of external mould of dorsal valve, detail of ornamentation ( $\times 4.5)$; E, F - MW 289d/54.10.00, lectotype, internal mould of ventral valve (E), lateral view (F). - G-N - Rhenostropheodonta rhenana gen. nov. et sp. nov.; stratum: Hohenrhein Formation; G, H - MB.B. 3163.1a, paratype; external mould of dorsal valve, top view $(\mathrm{G})$ and detail $(\times 3.7)$ of ornamentation $(\mathrm{H})$; locality: Hohenrheiner Hütte near Lahnstein; I-L - SMF 66712, holotype, internal mould of ventral valve, top (I), posterior (J) and lateral (K) views of internal mould, top view of latex cast (L); locality: Miellen, Lahn river, leg. F. Drevermann; M, N - SMF 93653.2; internal mould of dorsal valve (M) and latex cast (N); locality as before. • O, P - Rhenostropheodonta piligera (G. \& F. Sandberger, 1856); collection IPB, unnumbered; locality: Niederfell, Mosel river, leg. H. Ristedt; stratum: Laubach Group; internal mould of ventral valve, top $(\mathrm{O})$ and lateral $(\mathrm{P})$ views. 


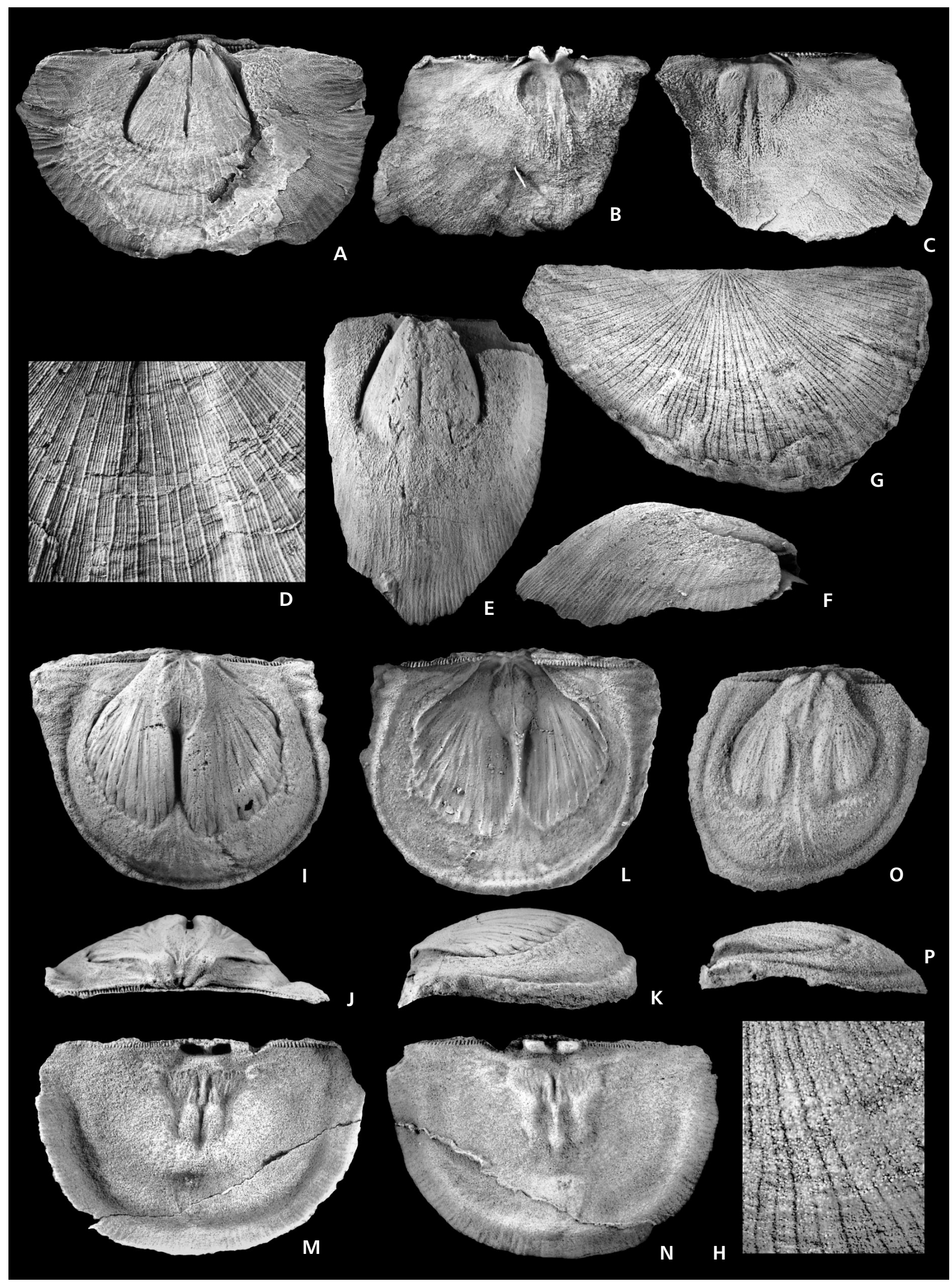


clearly developed paradental plates and the presence of a dorsal median ridge starting from the notothyrial platform and separating the adductor field. Bojodouvillina has a ventral muscle field with cordate outline accompanied by abbreviated muscle-bounding ridges. These differences allow a clear distinction of the two genera. Further genera of the same subfamily are not closely related to the new genus.

\section{Gibbodouvillina taeniolata (G. \& F. Sandberger, 1856)} Figure 5A-F

$$
\begin{aligned}
& \text { v * } 1856 \text { Strophomena taeniolata G. \& F. Sandberger, pp. 360, } \\
& \text { 361, pl. 34, figs 11, 11a, 11b. } \\
& \text { v } 1916 \text { Stropheodonta taeniolata. - Dahmer, pp. 235-237, } \\
& \text { pl. 9, fig. } 16 \text {. } \\
& 1941 \text { Stropheodonta taeniolata - Maillieux, p. } 25 . \\
& \text { v } 1954 \text { Stropheodonta taeniolata. - Rösler, pp. 31-33, pl. 3, }
\end{aligned}
$$

Lectotype. - Internal mould of articulated valves; the dorsal internal mould is still connected with the embedding rock, inventory numbers MW 289d/54.10.00, designated as lectotype and figured by Rösler (1954, p. 31, pl. 3, fig. 1); stored in the Museum Wiesbaden, Sandberger collection, probably the specimen figured by G. \& F. Sandberger (1856, pl. 34, fig. 11a; figure strongly idealized, may represent a composite of more than one specimen); the specimen is figured in the present work in Fig. 5E, F. Dimensions: $\mathrm{W}=26.3 \mathrm{~mm}, \mathrm{~L}=34.5 \mathrm{~mm}$ [laterally compressed].

Type stratum and locality. - Beds of Late Emsian age at the locality "Niederlahnstein", according to Rösler (1954, p. 32) very probably "Allerheiligenberg", central Middle Rhine region, Rhenish Slate Mountains, Germany.

Material. - All specimens come from Late Emsian strata of the Rhenish Slate Mountains. - Central Middle Rhine region. Type series from Niederlahnstein; Sandberger collection: 1 AVIM [lectotype MW 289d/54.10.00], 1 VVIM [paralectotype MW 289c/54.10.01], 1 VVIM, 1 DVEM [paralectotypes MW 289b/54.10.03], 1 DVIM [paralectotype MW 289a/54.10.02], 1 DVEM [paralectotype MW 289e/54.10.04]. - Further specimens from the central Middle Rhine region. Laubach Group, Dörrbach Valley near Koblenz; leg. G. Solle: 4 VVIM+EM [cf. taeniolata, SMF 85226, 93640, 93641; MB.B. 9106]. "Gegend von Coblenz”; leg. L. von Buch: 2 VVIM, 1 VVEM [MB.B. 9107]. - Eifel region. Wetteldorf Fm. (?), foot of Hartberg opposite Dürrkopf, near Prüm; leg. Rud. Richter: 1 VVIM [SMF 85223]. - Luxembourg. Erpeldinge, church yard at the bridge: 1 VVIM [SMF 85224]. - Lahn Synclinorium. Altenvers, hill W of the village; leg. U. Jansen: 1 VVIM [SMF 85225]. - Dill Synclinorium. Mandeln Fm., Hauberg near Mandeln; leg. G. Dahmer: 1 VVIM [SMF 66997]. Haigerseelbach; leg. Wagner: 1 VVIM [SMF 85675]. Haigerhütte Fm., Haigerhütte, NE slope of the Dill Valley between Hausberg and Schlierberg, E of Haiger: 1 VVIM [cf. taeniolata; USNM 220612].

Description. - Shells of moderate size, semielliptical in outline, slightly longer than wide or about as long as wide,

Figure 6. Selection of strophomenid brachiopods from the uppermost Silurian, Lower Devonian and lowermost Middle Devonian of the Rhenish Slate Mountains, Germany. • A, B - Leptostrophiella explanata (Sowerby, 1842); locality: Oberstadtfeld, S Central Eifel region; stratum: Stadtfeld Formation, upper Lower Emsian; A - SMF 66994; internal mould of ventral valve (× 1.0); B - SMF 66995; latex cast of internal mould of dorsal valve (× 1.0). - C, D - Douvillinella filifer (W.E. Schmidt, 1914); stratum: Heisdorf Fm., uppermost Upper Emsian; C - SMF 66169; internal mould of ventral valve (× 1.5); locality: Benenberg, near Blankenheim, North Eifel region; leg. L. Dickfeld; D - SMF 66168, internal mould of dorsal valve ( $\times 1.5)$; locality: Wehlert, field between Wehlert and Rommersheimerheld, Prüm Syncline, Eifel region; leg. R. Werner 1964. • E, F - Pseudoleptostrophia dahmeri (Rösler, 1954); leg. G. Fuchs; middle Lower Emsian; E - SMF 66166; internal mould of ventral valve (× 1.0); locality: Niederstadtfeld, Lauzert, S Central Eifel region; stratum: Gefell Formation; F-SMF 66167; latex cast of internal mould of dorsal valve ( $\times 1.0)$; locality: N exit of Altscheuern, West Eifel region; stratum: Altscheuern Formation. • G - Teichostrophia lepis subtilis Struve, 1992; SMF 50159, holotype; internal mould of ventral valve (× 2.3); locality: Honigseifen, bad lands near path, Salmerwald Syncline, Eifel region, leg. I. \& W. Struve \& H.O. Nürnberg (1968); stratum: Lauch Formation, lowermost Eifelian. • H, I - Crinistrophia elegans (Drevermann, 1902); locality: Oberstadtfeld; stratum: Stadtfeld Fm., upper Lower Emsian; H - SMF-Mbg. 2950, lectotype; internal mould of dorsal valve (× 1.3); I - SMF-Mbg. 2949, paralectotype; internal mould of ventral valve $(\times 1.3)$. $\bullet \mathrm{J}-$ Plicostropheodonta virgata (Drevermann, 1902); SMF-Mbg. 2946, paralectotype; external mould of dorsal valve (× 1.3); locality: Oberstadtfeld; stratum: Stadtfeld Formation, upper Lower Emsian. • K, L - Plicostropheodonta murchisoni (d'Archiac \& de Verneuil, 1842); locality: Haberscheid near Seifen, Westerwald, leg. U. Jansen; stratum: Seifen Formation, upper Middle Siegenian; K - SMF-Mbg. 5138; internal mould of ventral valve (× 1.3); L - SMF-Mbg. 5139; external mould of dorsal valve (× 1.3). • M - Fascistropheodonta sedgwicki (d'Archiac \& de Verneuil, 1842); SMF-Mbg. 2347; external mould of dorsal valve (× 1.3); locality: Seifen; stratum: Seifen Formation, upper Middle Siegenian. - N, O - Mesodouvillina triculta (Fuchs, 1919); locality: Hüinghausen, railway station, Ebbe Anticlinorium, Sauerland, leg. Rud. Richter; stratum: Hüinghausen Formation, Lower Gedinnian; N - SMF 93623, internal mould of dorsal valve $(\times 1.3)$; O - SMF 93632, internal mould of ventral valve $(\times 1.3)$. $\bullet$ - Shaleria rigida (de Koninck, 1876); SMF 66175; internal mould of ventral valve $(\times 1.3)$; locality: Weismes, Klein's quarry, Belgium; stratum: Gdoumont Formation, Př́idolian. 


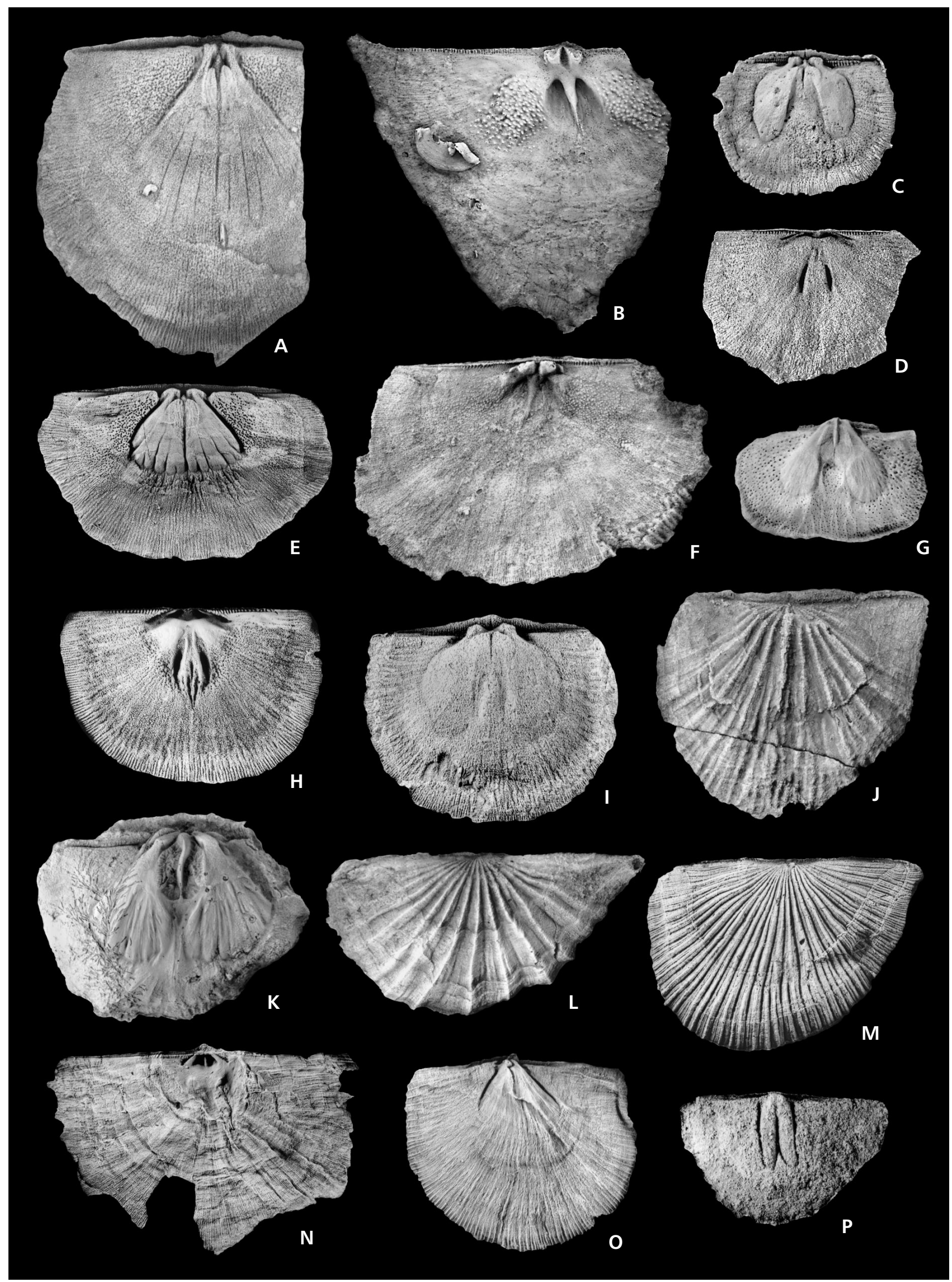


slightly brachythyrid; shells strongly concavo-convex to dorsally geniculate in profile. Ornamentation distinctly interstriate, consisting of numerous costellae separated by interspaces with groups of mostly 2 to 7 capillae increasing by insertion; new costellae normally develop from a capilla in the middle of its group, when the number of capillae has reached 5 or 6 ; costellae and capillae crossed by numerous concentric fila. Hinge line denticulate for about two thirds to all of its length. Interior of ventral valve with pyramid-shaped ventral process, giving rise to a median ridge bisecting the whole muscle field and a pair of short, diverging lateral ridges; ventral process laterally flanked by prominent cavities for the reception of the cardinal process lobes; pair of distinct paradental plates lateral to these cavities present. Ventral muscle field moderately large, semielliptical to piriform in outline, impressed, reaching about $2 / 5$ of valve length, subdivided into a pair of posteromedial adductor scars and a pair of anterolateral diductor scars. Diductor scars essentially smooth apart from an indistinct radial striation, enclosing dendritic adductor scars anteriorly. Muscle field laterally delimited by diverging, strong and sharply defined muscle-bounding ridges; these are convexly curved outwards and commonly continue as very low ridges along the anterior margin of the muscle field. Cardinal process bilobed, laterally flanked by moderately long, widely divergent brachiophores. Paired dorsal adductor scars distinct, slightly impressed, separated by median ridge starting from the notothyrial platform, each adductor scar subelliptical in outline; additional narrow adductor scars may be located anteromedially; lateral muscle-bounding ridges very low, poorly developed. Pair of straight medial septa present, elongate, developed as low and tuberculate ridges, starting posteromedially from the median ridge between the adductor scars and ending at about half length of valve, diverging at about a $15^{\circ}$ angle; central breviseptum poorly developed.

Discussion. - The species is in need of further revision. In its actual wide sense, it occurs as an accessory component of many Late Emsian faunas. At least closely related forms rarely occur in the Lower Emsian of the Taunus (own data) and the Eifel region (Rösler 1954), whereas the specimen described from the Erbsloch-Grauwacke (Kellerwald) by Jahnke (1971, pp. 64, 65, pl. 4, fig. 7) shows a different shape of the ventral muscle field and rudimentary paradental plates; the form may represent a separate species. Still undescribed, closely related representatives of Gibbodouvillina (possibly new species) are known to the present author from the Lower/Upper Emsian boundary beds of the Mdâouer-el-Kbîr Formation in S Morocco (Foum Zguid section; Jansen 2001) and from the Upper Emsian of the Cinco Villas Massif in the Basque Pyrenees, Spain (collection H. Requadt, Senckenberg Museum). Jahnke (1981, p. 157) reported G. taeniolata from the Emsian of the Ar- morican Massif in France and from the earliest Eifelian Lauch Formation (Eifel region). "Douvillina" interstrialis sensu Gratsianova, 1975 (non Phillips, 1841) from the Gorny Altai Mountains (SW Siberia) is similar, as well; it shows paradental plates and differs from G. taeniolata in the presence of faint concentric rugae and a relatively wider ventral muscle field. Another comparable species is Bojodouvillina transversa Su, 1976 from N China.

Gibbodouvillina taeniolata differs from the Middle Devonian Gibbodouvillina interstrialis (Phillips, 1841) from West and Central Europe by larger shells with narrower outline, whereas the outline of the ventral muscle field and the morphology of the dorsal interior are rather similar and indicate the congenerity (see figures in Biernat 1966 and Halamski 2009).

\section{Biostratigraphical implications of the Rhenish Strophomenida}

The Strophomenida are useful guide fossils in the siliciclastic-marine, rhenotypic facies of the Lower Devonian, as has already been pointed out earlier (Jansen 1998a, b). In this chapter, the succession of biostratigraphically significant taxa from the Přídolian to the lower Middle Devonian is described. The taxon ranges are shown in Fig. 7. The same species or at least closely related ones are known from sections in W and SW Europe, and North Africa, as well, so that they are useful in supraregional stratigraphical correlation.

1. The oldest species to be mentioned is Shaleria rigida (de Koninck, 1876) (Fig. 6P) indicating a latest Silurian (Př́idolian) age of the Gdoumont Formation (surrounding area of the Stavelot-Venn Anticlinorium), the Köbbinghausen Formation (Remscheid Anticlinorium) and the Kellerskopf Formation (S Taunus) ( $c f$. Godefroid \& Cravatte 1999). The Silurian/Devonian boundary beds of the Remscheid Anticlinorium contain further "stropheodontoid" taxa of "bohemotypic habitus" still to be investigated. [Remark: Substantial parts of the classical Gedinnian in its Ardennan type region turned out to be of latest Silurian age due to the occurrences of Dayia shirleyi Alvarez \& Racheboeuf, 1986, Quadrifarius dumontianus (de Koninck, 1876) and Shaleria rigida (de Koninck, 1876) (see Godefroid \& Cravatte 1999). It is proposed to use the term "Lowermost Gedinnian" for these Přídolian to probably basal Lochkovian parts of the classical Gedinnian successions which should include in the Ardennan area the lower part of the Muno Formation (the two "faunas of Ruisseau des Roches") and the Gdoumont Formation, in the Rhenish area the correlatives Köbbinghausen and Kellerskopf (= "Graue Phyllite") formations and the lower part of the Silberg Formation (Müsen Horst).]. 


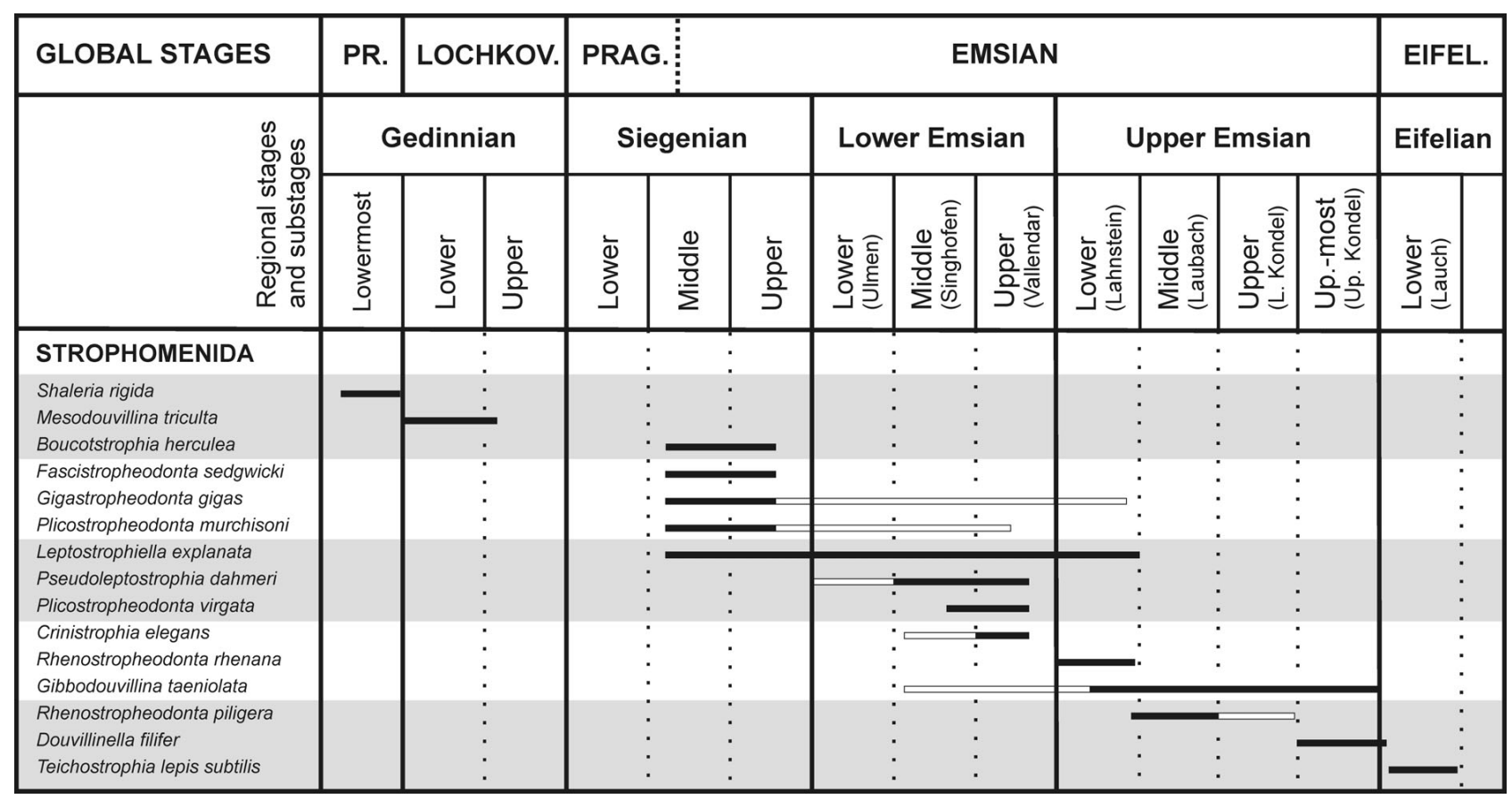

Figure 7. Stratigraphic ranges of Př́dolian to Early Eifelian Strophomenida from the Rhenish Slate Mountains (Germany). Ranges of $c f$. forms shown as white bars. PR. = Přídolian. The position of the basal Emsian boundary level in global (GSSP) sense is still uncertain; the current boundary is tentatively indicated (dotted line).

2. The Rhenish Lower Gedinnian ( lower Lochkovian) is characterised by Mesodouvillina triculta (Fuchs, 1919) (Fig. 6N, O). The species is particularly abundant in the Flaserschiefer Member of the Hüinghausen Formation in the Ebbe Anticlinorium (Sauerland) where it forms plasters on bedding surfaces, but it occurs in other members of the same formation and in the overlying Bredeneck Formation, as well (Eiserhardt et al. 1981, p. 214).

3. Following a Late Gedinnian to Early Siegenian gap of marine documentation a number of strophomenid brachiopods immigrated with the Middle Siegenian transgression, for example Leptostrophiella explanata (Sowerby, 1842), Boucotstrophia herculea (Drevermann, 1904), Plicostropheodonta murchisoni (d'Archiac \& de Verneuil, 1842) (Fig. 6K, L), Fascistropheodonta sedgwicki (d'Archiac \& de Verneuil, 1842) (Fig. 6M) and Gigastropheodonta gigas (McCoy, 1852). Boucotstrophia herculea and Fascistropheodonta sedgwicki are most common in the Middle Siegenian, so that they can be regarded almost as index fossils of this substage, but both occur as rare elements of Late Siegenian faunas, as well. A Middle to Late Siegenian early form of Leptostrophiella explanata can be distinguished from conspecific Emsian descendants by the morphology of its ventral muscle field and the muscle-bounding ridges ( $c f$. Jahnke 1971, Jansen, in prep.). Gigastropheodonta gigas and Plicostropheodonta murchisoni are probable guide fossils of the Middle to Upper Siegenian interval. The congeneric representatives from overlying Emsian strata previously assigned to the same species are different in various respects and may turn out as separate species (Jansen, in prep.).

4. Leptostrophiella explanata (Sowerby, 1842) sensu stricto (Fig. 6A, B), Pseudoleptostrophia dahmeri (Rösler, 1954) (Fig. 6E, F), Crinistrophia elegans (Drevermann, 1902) (Fig. 6H, I) and Plicostropheodonta virgata (Drevermann, 1902) (Fig. 6J) represent guide fossils of the Lower Emsian. Typical forms of $P$. dahmeri seem to have their onset near the lower boundary of the middle Lower Emsian ("Singhofen") and are common in middle and upper parts of the Lower Emsian ("Singhofen" and "Vallendar"), mainly in the Gefell and Stadtfeld formations (S Central Eifel region) and the Ergeshausen and Spitznack formations (Taunus). Crinistrophia elegans is most abundant in the Stadtfeld Formation, but the genus occurs with few, probably conspecific specimens in older beds of the Spitznack Formation. Plicostropheodonta virgata sensu stricto seems to be confined to middle and upper parts of the Lower Emsian, in particular the Oppershofen Formation (NE Taunus) and the Stadtfeld Formation (S Central Eifel region). A comprehensive revision of all these taxa would be necessary to clarify their exact ranges. What can nearly be excluded is an upper range of these into the Upper Emsian.

5. Rhenostropheodonta rhenana gen. nov. et sp. nov. has its first occurrence in the earliest Late Emsian Emsquarzit Formation where it is so common that it is useful as 
a marker for the beginning of the Upper Emsian. It has its highest abundance in the overlying Hohenrhein Formation, where it may occur even in masses. The species appears to be restricted to the Lahnstein Group. It is also present in the Wiltz Formation of the Prüm Syncline (Eifel region). A form determined as Fascistropheodonta sedgwicki from the Wiltz Formation (Harper \& Boucot 1978c, p. 25, pl. 45, figs $4,5,7,8$, pl. 46, figs $1,3,4,5$ ?) does not belong to this species, but to a still undescribed one restricted to the Upper Emsian.

6. Rhenostropheodonta piligera (G. \& F. Sandberger, 1856) has a shorter range than hitherto reported because is has not been distinguished from $R$. rhenana so far. According to the present knowledge, the species is restricted to middle parts of the Upper Emsian, i.e. the Laubach Group and probably highest parts of the Hohenrhein Formation. Descendants reach into the Kondel Group.

7. The Late Emsian leptostrophiids are still in need of revision. Recently (2012), the author discovered a mass occurrence of Leptostrophiella explanata (late form) in the Hohenrhein Formation of the Siechhaus Valley near Koblenz. Besides, there are probable new leptostrophiid taxa from the Wetteldorf Formation (Eifel region) and the Kondel Group (Dill Synclinorium).

8. Douvillinella filifer (W.E. Schmidt, 1914) (Fig. 6C, D) is a chiefly late Late Emsian taxon and a typical faunal component of the Heisdorf Formation (Eifel region; Werner 1969). It just ranges into the basal Eifelian (Polygnathus partitus Zone). Besides, the species has been reported from lower and upper parts of the Kondel Group (Jahnke 1981; Solle 1976, p. 170).

9. Teichostrophia lepis subtilis Struve, 1992 (Fig. 6G) is possibly restricted to the Early Eifelian Lauch Formation of the Eifel region (Struve 1992, p. 543: "anscheinend ein Leitfossil des Lauchium" = "apparently a guide fossil of the Lauchian") or has at least its main distribution here.

\section{Palaeobiological aspects}

During the Early Devonian, huge amounts of siliciclastic material were transported by rivers and deltas from the Old Red Continent in the north into the shallow Rhenish Sea. The Rhenish brachiopods were adapted to the conditions of siliciclastic shelf environments. Strong currents and turbulence could whirl up the sediments, destabilize the substrate, scour the sediment around the shells or even set the brachiopods in motion. The brachiopods as sessile, microphagous suspension-feeders benefited from the well-oxygenated and nutrient-rich conditions of the rhenotypic facies, but had to tolerate agitated, turbid water, as well. Stable hard grounds were probably rare. Frequent destruction of biocoenoses ("lethal-heterostrate facies" sensu Schäfer 1962) during sudden erosion or sedimentation events and high mortality rates were probably compensated by high reproduction rates. Due to a good supply of nutrients and enough calcium carbonate, representatives of Boucotstrophia or Gigastropheodonta could secrete large and thick shells, preventing the brachiopods from being moved across the sea-floor or turned over by currents.

Strongly plicate shells of Plicostropheodonta had the advantage that with the same opening angle of the shell the plications provided a better protection against coarsegrained particles entering the mantle cavity, which could have obstructed or damaged the filter apparatus (Rudwick 1970, Gourvennec 1989). The plications may also have strengthened the shells against durophagous predators, following the principle of a corrugated cardboard.

Leptostrophiella, Boucotstrophia, Gigastropheodonta and Rhenostropheodonta had large ventral diductor fields reflecting a strong musculature. Strong muscles were possibly needed to keep the commissure width constantly narrow even in episodes of strong turbulence or flow. If the gap between the valves was too wide, too coarse particles could come into the mantle cavity, whereas the inhalantexhalant system could collapse, if the two valves collided. Both situations had to be avoided. It was like keeping a door open with a narrow gap against a wind of variable strength ( $c f$. Carls et al. 1993).

Relatively flat-shelled strophomenids, such as Leptostrophiella, Mesodouvillina or Pseudoleptostrophia could have been adapted to high-energy and hard-substrate environments, as they profited from a flat profile by experiencing less drag and a decreased likelihood of hydrodynamic transport. Boucotstrophia and Gigastropheodonta most probably lived with the flat posterior part of the ventral valve bottom on soft substrates and with the anterior trail directed upward, so that they lifted their anterior commissures above the siliciclastic substrate in order to avoid that mobile sand grains entered the mantle cavity. The form enabled these to employ an "iceberg" strategy, floating convex down on the soft substrate (Thayer 1975, Leighton \& Savarese 1996, Leighton 1998).

\section{Conclusions}

The Strophomenida from the Rhenish Lower Devonian have poorly been studied up to the present day. A comprehensive revision is prepared by the author, and first results are presented in this work. Three genera are described as new because their species did not fit well in the genera they have previously been included in: Gigastropheodonta [type species: Leptaena (Strophomena) gigas McCoy, 1852], Rhenostropheodonta (type species: $R$. rhenana gen. nov. et sp. nov.) and Gibbodouvillina (type species: Strophomena taeniolata G. \& F. Sandberger, 1856). These genera are compared with presumably related taxa, in the 
case of the latter two with genera from North America, to which their species have previously been assigned. The widely misunderstood genus Boucotstrophia Jahnke, 1981 is revised, excluded from the family Strophodontidae Caster, 1939 and included in the subfamily Mesodouvillininae Harper \& Boucot, 1978b. Further strophomenid taxa are briefly discussed.

Rhenish strophomenids have a great biostratigraphic potential, as they have short ranges and occur in abundance and in different subtypes of the rhenotypic facies. The Lowermost Gedinnian (Príidolian) is characterised by the typically Silurian element Shaleria rigida (de Koninck, 1876), the Lower Gedinnian by Mesodouvillina triculta (Fuchs, 1919) and the Middle-Upper Siegenian interval mainly by Boucotstrophia herculea (Drevermann, 1904), Gigastropheodonta gigas (McCoy, 1852) and Fascistropheodonta sedgwicki (d'Archiac \& de Verneuil, 1842). The Lower Emsian is indicated by the occurrence of Pseudoleptostrophia dahmeri (Rösler, 1954), Plicostropheodonta virgata (Drevermann, 1902) and Crinistrophia elegans (Drevermann, 1902), whereas the lower boundary of the Upper Emsian can well be recognized by the onset of Rhenostropheodonta rhenana gen. nov. et sp. nov. The Upper Emsian is indicated by this species and typical specimens of Gibbodouvillina taeniolata (G. \& F. Sandberger, 1856) and Rhenostropheodonta piligera (G. \& F. Sandberger, 1856), the latter one having a potential as guide fossil for the middle part of the Upper Emsian ("Laubach substage"). The uppermost Upper Emsian is well documented by Douvillinella filifer (W.E. Schmidt, 1914), and an indicator for the beginning of the Eifelian is the first Teichostrophia lepis subtilis Struve, 1992. The study of phylogenetic changes within the strophomenid taxa may open further possibilities of stratigraphic subdivision in the future. Because the same or similar species are distributed in W and SW Europe and North Africa new possibilities of far-reaching correlations can be expected. Strophomenid brachiopods are almost omnipresent in shallow-marine successions of the rhenotypic Lower Devonian and apparently follow the general faunal patterns or, respectively, the subdivision into ecological-evolutionary subunits as reflected by the succession of brachiopod faunas (Jansen, in prep.).

As regards palaeobiogeography, the results from the Rhenish strophomenids are consistent with the assumed presence of a Maghrebo-European Subrealm within the Old-World Realm during the Early Devonian, which is suggested by the distribution of brachiopod faunas as a whole ( $c f$. Jansen 2012a, b; based on Plusquellec et al. 1997). The occurrence of Rhenish strophomenid genera in regions outside Europe and North Africa is still to be verified. Morphologically "conservative" genera such as Leptostrophiella or Mesodouvillina which have been reported from different regions worldwide (see, e.g., Harper
\& Boucot 1978a, b; Talent et al. 2001) still should be compared side-by-side with the Rhenish forms in order to better specify their relationships. In the North Gondwanan regions, i.e. Armorican Massif, Celtiberian Chains, Cantabrian Mountains, Sierra de Guadarrama, Dra Plains and Ougarta Chains, even the same brachiopod species as in the Rhenish Slate Mountains occur, sometimes geographical races, subspecies or at least closely related species. The present data suggest their affiliation to a joint palaeobiogeographic unit.

\section{Acknowledgements}

Many thanks are due to Erika Scheller-Wagner, who did a lot of the technical work necessary as preparation of fossils, putting them into the archives and preparing marvellous latex casts. The final chemical development of the photographs was only possible with the kind permission by Rainer Brocke to use his laboratory and the friendly help of his technical assistant Jutta Oelkers-Schaefer. Claudia Groth, Juliane Eberhardt, Gunnar Riedel and Alexander Horn much supported the work with respect to technical work and collection management. Internship student Susan Irene Anderko (Bad Vilbel) carried out a statistical analysis of the Rhenostropheodonta species, and Etienne Neuhaus (University of Mainz) helped in the technical preparation of the plates. My special thanks go to Gerhard Plodowski who sparked my interest in strophomenid brachiopods in the early nineties. I thank many colleagues from various museums and institutions who helped during my visits, gave me access to the collections and allowed the loan of materials: Dieter Korn, Martin Aberhan, Henning Scholz, Cornelia Tilling and Sylvia Salzmann (Museum für Naturkunde, Berlin), Michael Amler (University of Cologne), Günther Kaufmann (former Institute of Geology and Palaeontology, Marburg a. d. Lahn), Fritz GellerGrimm and Gerhard Heinrich (Museum Wiesbaden), Doris Heidelberger (Oberursel), Martin Munt and Sarah Long (Natural History Museum, London, Great Britain), Bushra Hussaini and Neil Landman (American Museum of Natural History, New York City, USA), Dan Levin and Mark Florence (Smithsonian United States National Museum of Natural History, Washington D.C., USA), and Susan Butts and Derek Briggs (Peabody Museum of Natural History, Yale University, New Haven/CT, USA). Peter Carls (formerly University of Braunschweig) left his valuable brachiopod collections from the Rhenish Lower Devonian including many important specimens to my section in the Senckenberg Museum. The private collectors Eva Grebel (Dierdorf/Westerwald) and Ralf Seibert (Ransbach-Baumbach) provided a number of important specimens for study. It thank the reviewers Andrzej Baliński (Instytut Paleobiologii PAN, Warszawa) and Fernando Alvarez (University of Oviedo) for their thorough reviews and very helpful comments. The curatorial work in the Senckenberg collections was financially supported by the German Research Foundation (DFG, LIS Programme; INST 21964/1-1). The present work is a contribution to IGCP 596 "Climate change and biodiversity patterns in the Mid-Palaeozoic". 


\section{References}

Aït-Malek, Z., Racheboeuf, P.R. \& LaZreQ, N. 2000. Nouveaux brachiopodes Strophomenata du Dévonien inférieur de l'Anti-Atlas occidental, Maroc. Geobios 33, 309-318. DOI 10.1016/S0016-6995(00)80160-6

Alvarez, F. \& Racheboeuf, P.R. 1986. Sous-famille Dayiinae Waagen, 1883, 128-131. In RacheBoeuf, P.R. (ed.) Le Groupe de Liévin. Pridoli-Lochkovien de l'Artois (N. France). Sédimentologie - Paléontologie - Stratigraphie. Biostratigraphie du Paléozoïque 3.

Archiac, E.A.J.D. D' \& Verneuil, E. De 1842. Memoir on the fossils of the older deposits in the Rhenish provinces, preceded by a general survey of the fauna of the Palaeozoic rocks, and followed by a tabular list of the organic remains of the Devonian system in Europe. Text and plates. Transactions of the Geological Society of London 2, 6(2), 5-40 + 303-410.

BÉClARD, F. 1887. Les fossiles coblenziens de St. Michel près de Saint Hubert. Bulletin de la Société belge de Géologie, de Paléontologie et d'Hydrologie 1, 60-97.

Biernat, G. 1966. Middle Devonian brachiopods of the Bodzentyn Syncline (Holy Cross Mountains, Poland). Palaeontologia Polonica 17, 1-162.

Boucot, A.J. 1960. A new Lower Devonian stropheodontid brachiopod. Journal of Paleontology 34(3), 483-485.

CARLS, P. 1987. Ein Vorschlag zur biostratigraphischen Redefinition der Grenze Gedinnium/Siegenium und benachbarter Unterstufen. 1. Teil Stratigraphische Argumente und Korrelation. Courier Forschungsinstitut Senckenberg 92, 77-121.

Carls, P., Meyn, H. \& Vespermann, J. 1993. Lebensraum, Entstehung und Nachfahren von Howellella (Iberohowellella) hollmanni n. sg., n. sp. (Spiriferacea; Lochkovium, UnterDevon). Senckenbergiana lethaea 73(2), 227-267.

Carls, P. \& Valenzuela-Ríos, J.I. 1998. The ancestry of the Rhenish Middle Siegenian brachiopod fauna in the Iberian Chains and its palaeozoogeography (Early Devonian). Revista Española Paleontología, No. extr., Homenaje al Prof. Gonzalo Vidal, 123-142.

CAster, K.E. 1939. A Devonian fauna from Colombia. Bulletins of American Paleontology 24(83), 1-219.

CAster, K.E. 1945. Paleontological notes. New names for two homonyms. Journal of Paleontology 19(3), 319.

Cocks, R. \& Rong, J.-Y. 2000. Strophomenida, 216-349. In KAESLER, R.L. (ed.) Treatise on Invertebrate Paleontology, Part H, Brachiopoda (revised), Vol. 2: Linguliformea, Craniiformea, and Rhynchonelliformea (part). Geological Society of America \& University of Kansas, Lawrence, Kansas.

CONRAD, T.A. 1842. Observations on the Silurian and Devonian systems of the United States with descriptions of new organic remains. Journal of the Academy of Natural Sciences of Philadelphia 8, 228-280.

DAHMER, G. 1916. Die Fauna der obersten Koblenzschichten von Mandeln by Dillenburg. Jahrbuch der Königlich Preussischen Geologischen Landesanstalt zu Berlin für das Jahr 1915, 36(1), 174-248.

Dahmer, G. 1934. Die Fauna der Seifener Schichten (Siegenstufe). Abhandlungen der preussischen geologischen Landesanstalt, Neue Folge 147, 1-91.

DAHMER, G. 1951. Die Fauna der nach-ordovizischen Glieder der
Verseschichten. Mit Ausschluß der Trilobiten, Crinoiden und Anthozoen. Palaeontographica, Abteilung A 101(1-4), $1-152$.

Davidson, T. 1865. A Monograph of British Devonian Brachiopoda 6. Palaeontographical Society Monograph 8, 1-30.

Drevermann, F. 1902. Die Fauna der Unterkoblenzschichten von Oberstadtfeld bei Daun in der Eifel. Palaeontographica 49, 73-120.

Drevermann, F. 1904. Die Fauna der Siegener Schichten von Seifen unweit Dierdorf (Westerwald). Palaeontographica 50, 229-287.

Drevermann, F. 1907. Paläozoische Notizen. Bericht der Senckenbergischen Naturforschenden Gesellschaft Frankfurt a. M. 1907, 125-136.

Eiserhardt, K.H., Heyckendorf, K. \& Thombansen, E. 1981. Zur Stratigraphie und Tektonik des nördlichen Ebbe-Teilsattels (Sauerland, Rheinisches Schiefergebirge). Mitteilungen des Geologisch-Paläontologischen Institutes der Universität Hamburg 50, 199-238.

FRECH, F. 1897. Lethaea palaeozoica, 2. Band, 1. Lieferung. Lethaea geognostica 1. 256 pp. E. Schweizerbart'sche Verlagshandlung (E. Koch), Stuttgart.

Fuchs, A. 1915. Die Hunsrückschiefer und die Unterkoblenzschichten am Mittelrhein (Loreleigegend). I. Teil: Beitrag zur Kenntnis der Hunsrückschiefer- und Unterkoblenzfauna der Loreleigegend. Abhandlungen der preussischen geologischen Landesanstalt, Neue Folge 79, 1-79.

Fuchs, A. 1919. Beitrag zur Kenntnis der Devonfauna der Verseund der Hobräcker Schichten des sauerländischen Faciesgebietes. Jahrbuch der preussischen geologischen Landesanstalt für 1918, 39(1), 58-95.

GAD, J. 1997. Eine neue Brachiopodengattung Pseudoleptostrophia aus dem Unterdevon des Rheinischen Schiefergebirges und ergänzende morphologische Daten über die Typusart Pseudoleptostrophia dahmeri. Mainzer geowissenschaftliche Mitteilungen 26, 191-200.

García-Alcalde, J.L. 1992. El Devónico de Santa María del Mar (Castillón, Asturias, Espańa). Revista Española de Paleontología 7(1), 53-79.

German Stratigraphic Commission (ed.) 2002. Stratigraphic Table of Germany 2002 (STG 2002). GeoForschungsZentrum \& Forschungsinstitut Senckenberg, Potsdam \& Frankfurt am Main.

Godefroid, J., Blieck, A., Bultynck, P., Dejonghe, L., GerRienne, P., Hance, L., Meilliez, F., Stainier, P. \& Steemans, P. 1994. Les formations du Dévonien inférieur du Massif de la Vesdre, da la Fenêtre du Theux et du Synclinorium de Dinant (Belgique, France). Mémoires pour servir à l'Explication des Cartes Géologiques et Minières de la Belgique 38, 1-144.

Godefroid, J. \& Cravatte, T. 1999. Les brachiopodes et la limite Silurien/Dévonien à Muno (sud de la Belgique). Bulletin de l'Institut royal des Sciences naturelles de Belgique 38, 5-26.

Gosselet, J. 1880. Esquisse géologique du Nord de la France et des contrées voisines. Premier fascicule: Terrains primaire. 167 pp. Six-Horemans, Lille.

Gourvennec, R. 1989. Brachiopodes Spiriferida du Dévonien inférieur du Massif Armoricain. Systématique, paléobiologie, évolution, biostratigraphie. Biostratigraphie du Paléozoïque 9, 1-281. 
Gratsianova, R.T. 1975. Brakhiopody rannego i srednego devona Altae-sayanskoi oblasti, strofomenidy [Early and middle Devonian brachiopoda of the Altai-Sayan region: Strophomenidina]. Akademiya nauk SSSR, Sibirskoe otdelenie, Institut geologii i geofiziki, Trudy 248, 1-106. [in Russian]

Halamski, A.T. 2009. Middle Devonian Brachiopods from the northern Part of the Holy Cross Mountains, Poland in relation to selected coeval faunas. Palaeontographica, Abteilung A 287(1-3), 41-98.

Hall, J. 1850. On the Brachiopoda of the Silurian Period. Proceedings of the American Association for the Advancement of Science 2, 247-351.

Hall, J. 1857. Descriptions of new species of Palaeozoic fossils from the Lower Helderberg, Oriskany Sandstone, Upper Helderberg, Hamilton and Chemung Groups. New York State Cabinet of Natural History, $10^{\text {th }}$ Annual Report, 41-186. Albany.

HamadA, T. 1971. Early Devonian brachiopods from the Lesser Khingan district of Northeast China. Paleontological Society of Japan, Special Papers 15, 11-98.

HARPER, C.W. 1973. Brachiopods of the Arisaig group (Silurian-Lower Devonian) of Nova Scotia. Bulletin of the Geological Survey of Canada 215, 1-163.

Harper, C.W. \& Boucot, A.J. 1978a. The Stropheodontacea. Part I: Leptostrophiidae, Eostropheodontidae and Strophonellidae. Palaeontographica, Abteilung A 161(1-3), 55-118.

Harper, C.W. \& Boucot, A.J. 1978b. The Stropheodontacea. Part II: Douvillinidae, Telaeoshaleriidae, Amphistrophiidae and Shaleriidae. Palaeontographica, Abteilung A 161(4-6), 119-175.

Harper, C.W. \& Boucot, A.J. 1978c. The Stropheodontacea. Part III: Stropheodontidae (sensu strictu), Pholidostrophiidae and Lissostrophiidae. Palaeontographica, Abteilung A 162(1-2), 1-80.

HAVLÍ̌̌EK, V. 1967. Brachiopoda of the suborder Strophomenidina in Czechoslovakia. Rozpravy Ústředního ústavu geologického 33, 1-235.

JAHNKE, H. 1971. Fauna und Alter der Erbslochgrauwacke (Brachiopoden und Trilobiten, Unter-Devon, Rheinisches Schiefergebirge und Harz). Göttinger Arbeiten zur Geologie und Paläontologie 9, 1-105.

JAHNKE, H. 1981. Les brachiopodes Strophodontidae, 149-159. In Morzadec, P., Paris, F. \& Racheboeuf, P.R. (eds) La tranchée de la Lézais - Emsien supérieur du Massif Armoricain. Sédimentologie, paléontologie, stratigraphie. Mémoirs de la Société géologique et minéralogique de Bretagne 24.

JAHNKE, H. 1986. Superfamille Strophodontacea Caster, 1939, 107-111. In Racheboeuf, P.R. (ed.) Le Groupe de Liévin. Pridoli-Lochkovien de l'Artois (N. France). SédimentologiePaléontologie - Stratigraphie. Biostratigraphie du Paléozoïque 3.

JahnKe, H. \& Racheboeuf, P.R. 1980. Les brachiopodes Strophomenida, 203-210. In Plusquellec, Y. (ed.) Les Schistes et Calcaires de l'Armorique (Dévonien inférieur, Massif Armoricain). Sédimentologie, Paléontologie, Stratigraphie. Mémoirs de la Société géologique et minéralogique de Bretagne 23.

Jansen, U. 1994. Die Stropheodontacea (Brachiopoda) der Seifener Schichten (Unter-Devon, Westerwald). 100 pp. Diploma thesis, Philipps University Marburg/Lahn. [unpublished]
Jansen, U. 1998a. Anmerkungen zur Devon-Korrelationstabelle, B123di98: Strophomenida, Rheinisches Schiefergebirge. Senckenbergiana lethaea 78(1/2), 229-233.

Jansen, U. 1998b. Tabellen-Spalte B123di98: Strophomenida, Rheinisches Schiefergebirge, 246. In Weddige, K. (ed.) Devon-Korrelationstabelle. Senckenbergiana lethaea 78(1/2).

Jansen, U. 2001. Morphologie, Taxonomie und Phylogenie unter-devonischer Brachiopoden aus der Dra-Ebene (Marokko, Prä-Sahara) und dem Rheinischen Schiefergebirge (Deutschland). Abhandlungen der Senckenbergischen Naturforschenden Gesellschaft 554, 1-389.

JANSEN, U. 2012a. Die Welt des frühen Devons aus der Sicht der Brachiopodenforschung. Natur Forschung Museum 142(1/2), $44-51$.

JANSEN, U. 2012b. Revision of Rhenish Lower Devonian Brachiopoda, 86-87. In Witzmann, F. \& ABerhan, M. Centenary Meeting of the Paläontologische Gesellschaft. Programme, Abstracts, and Field Guides, 24.09.-29.09.2012, Museum für Naturkunde Berlin - Terra Nostra, Schriften der GeoUnion Alfred-Wegener-Stiftung 2012/3.

KegEL, W. 1913. Der Taunusquarzit von Katzenelnbogen. Abhandlungen der preussischen geologischen Landesanstalt, Neue Folge 76, 1-162.

KING, W. 1846. Remarks on certain genera belonging to the class Palliobranchiata. Annals and Magazine of Natural History, London 18, 26-42, 83-94.

KonINCK, L. DE 1876. Notice sur quelques fossiles recueillis par G. Dewalque dans le système Gédinnien de A. Dumont. Annales de la Société géologique de Belgique 3, 25-52.

KozŁowski, R. 1929. Les brachiopodes Gothlandiens de la Podolie Polonaise. Palaeontologia Polonica 1, 1-254.

Leighton, L.R. 1998. Constraining functional hypotheses: controls on the morphology of the concavo-convex brachiopod Rafinesquina. Lethaia 31, 293-307. DOI 10.1111/j.1502-3931.1998.tb00519.x

Leighton, L.R. \& SAvarese, M. 1996. Functional and taphonomic implications of Ordovician strophomenid brachiopod valve morphology, 161-168. In COPPER, P. \& JiN, J. (eds) Brachiopods. Proceedings of the Third International Brachiopod Congress Sudbury/Ontario/Canada/2-5 September 1995. A.A. Balkema, Rotterdam \& Brookfield.

Maillieux, E. 1936. La faune et l'âge des Quartzophyllades siegéniens de Longlier. Mémoires du Musée royal d'histoire naturelle de Belgique 73, 3-140.

Maillieux, E. 1941. Les brachiopodes de l'Emsien de l'Ardenne. Mémoires du Musée royal d'histoire naturelle de Belgique 96, $3-74$.

MAURER, F. 1883. Über das rheinische Unterdevon. Zeitschrift der deutschen Geologischen Gesellschaft 35, 633-635.

Maurer, F. 1893. Palaeontologische Studien im Gebiet des rheinischen Devon, 9. Mitteilungen über einige Brachiopoden aus der Grauwacke von Seifen. Neues Jahrbuch für Mineralogie, Geologie und Paläontologie 1, 1-14.

MaUZ, J. 1935. Vergleichende Untersuchungen über die Unterkoblenz-Stufe bei Oberstadtfeld und Koblenz. Abhandlungen der Senckenbergischen Naturforschenden Gesellschaft 429, 1-94.

McCoy, F. 1852. In Sedgwick, A. \& McCoy, F. 1851-1855. A synopsis of the classification of the British Palaeozoic rocks, with a detailed systematic description of the British Palaeo- 
zoic Fossils in the Geological Museum of the University of Cambridge. (1), 1851, i-iv, 1-184; (2), 1852, i-viii, 185-406; (3), 1855, i-xcviii, 407-661. J. W. Parker \& Son, London \& Cambridge.

McLearn, F.H. 1924. Palaeontology of the Silurian rocks of Arisaig, Nova Scotia. Canada Department of Mines, Geological Survey Memoir 137, 1-179.

OehLERT, D.-P. 1896. Fossiles dévoniens de Santa Lucía (Espagne). Bulletin de la Société géologique de France 3(24), 814-875.

Oehlert, D. \& Davoust, M. 1879. Sur le Dévonien du département de la Sarthe. Bulletin de la Société géologique de France 3(7), 697-717.

ÖPIK, A.A. 1934. Über die Klitamboniten. Tartu Ulikooli Geoloogia-Instituudi Toimestuesed Acta et Commentationes Universitatis Tartuensis 39, 1-239.

Paeckelmann, W. \& Sieverts, H. 1932. Neue Beiträge zur Kenntnis der Geologie, Palaeontologie und Petrographie der Umgegend von Konstantinopel. Abhandlungen der preussischen geologischen Landesanstalt, Neue Folge 142, 1-79.

PAPRoth, E. 1960. Über die Fauna der Mittleren Siegener Schichten des Siegerlandes. Abhandlungen des hessischen Landesamtes für Bodenforschung 29, 321-339.

PHILliPs, J. 1841. Figures and descriptions of the Palaeozoic fossils of Cornwall, Devon, and west Somerset. XII + 231 pp. Geological Survey of Great Britain, Memoir 1. Longman \& Co., London.

Plusquellec, Y., Boumendjel, K., Morzadec, P. \& Paris, F. 1997. Les faunes dévoniennes d'Ougarta dans la paléogéographie des régions maghrébo-européennes. Annales de la Société géologique du Nord 5 (2ème série), 123-128.

Poschmann, M. \& Jansen, U. 2003. Lithologie und Fossilführung einiger Profile in den Siegen-Schichten des Westerwaldes (Unter-Devon, Rheinisches Schiefergebirge). Senckenbergiana lethaea 83(1/2), 157-183.

RENOUF, J.T. 1972. Brachiopods from the Grès à Orthis monnieri Formation of northwestern France and their significance in Gedinnian/Siegenian stratigraphy of Europe. Palaeontographica, Abteilung A 139(4-6), 89-133.

RöSLER, A. 1954. Zur Fauna des rheinischen Unter-Devons. Notizblatt des hessischen Landesamtes für Bodenforschung 82, 30-37.

RuDwick, M.J.S. 1970. Living and fossil brachiopods. 199 pp. Hutchinson University Library, London.

SAndBerger, G. \& SAndberger, F. 1856. Die Versteinerungen des rheinischen Schichtensystems in Nassau. Mit einer kurzgefaßten Geognosie dieses Gebietes und mit steter Berücksichtigung analoger Schichten anderer Länder. Lfg. 8-9 [edition], I-XV, Bogen 30-71 [sheets printed in the edition], 233-564. Kreidel \& Niedner Verlagshandlung, Wiesbaden.

SCHÄFER, W. 1962. Aktuo-Paläontologie nach Studien in der Nordsee. 666 pp. Waldemar Kramer, Frankfurt am Main.

Schemm-Gregory, M. \& Henriques, M.H. 2013. Catalogue of the Krantz Brachiopod Collection at the Science Museum of the University of Coimbra (Portugal). Zootaxa 3677(1), Monograph, 1-173.

Schmid, W.E. 1914. Cultrijugatus-Zone und unteres Mitteldevon südlich der Attendorn-Elsper Doppelmulde. Jahrbuch der preussischen geologischen Landesanstalt für 1912, 33(2), 265-318.
Sokolskaya, A.N. 1960. Otriad Strophomenida, 206-220. In OrLov, Y.A. (ed.) Osnovy Paleontologii 7. Mshanki, brakhiopody [Bryozoa, Brachiopoda]. Akademiia Nauk SSSR, Moscow. [in Russian]

Solle, G. 1976. Oberes Unter- und unteres Mitteldevon einer typischen Geosynklinal-Folge im südlichen Rheinischen Schiefergebirge. Die Olkenbacher Mulde. Geologische Abhandlungen Hessen 74, 1-264.

Sowerby, J.G. 1842. Description of Silurian fossils from the Rhenish Provinces, 408-410. In ARCHIAC, E.A.J.D. D' \& VERNEUIL, E. de Memoir on the fossils of the older deposits in the Rhenish provinces. Transactions of the Geological Society of London 6(2).

Struve, W. 1992. Neues zur Stratigraphie und Fauna des rhenotypen Mittel-Devon. Senckenbergiana lethaea 71(5/6), 503-624.

Su, Y.Z. 1976. The brachiopods from Cambrian to Devonian, 155-227. In Northeast China Institute of GeOlogical SCIENCES (ed.) Atlas of fossils of North China. Inner Mongolia Volume, Part 1, Palaeozoic. Geological Publishing House, Beijing. [in Chinese]

Talent, J.A., Gratsianova, R.T. \& Yolkin, E.A. 2001. Latest Silurian (Pridoli) to Middle Devonian (Givetian) of the AsioAustralia hemisphere: rationalization of brachiopod taxa and faunal lists; stratigraphic correlation chart. Courier Forschungsinstitut Senckenberg 236, 1-221.

ThAYER, C.W. 1975. Morphological adaptations of benthic invertebrates to soft substrata. Journal Marine Research 33, $177-189$.

Weddige, K. (ed.) 1996. Beiträge zu Gemeinschaftsaufgaben der deutschen Subkommission für Devon-Stratigraphie, 1: Devon-Korrelationstabelle. Senckenbergiana lethaea 76(1/2), 267-286.

Weddige, K. (ed.) 1998a. Devon-Korrelationstabelle. Senckenbergiana lethaea 77(1/2), 289-326.

WedDige, K. (ed.) 1998b. Devon-Korrelationstabelle. Senckenbergiana lethaea 78(1/2), 243-265.

Weddige, K. (ed.) 2000. Devon-Korrelationstabelle. Senckenbergiana lethaea $80(2), 691-726$.

Werner, R. 1969. Ober-Ems und tiefstes Mittel-Devon am N-Rand der Prümer Mulde (Devon, Eifel). Senckenbergiana lethaea 50(2/3), 161-237.

WILLIAMS, A. 1950. New stropheodontid brachiopods. Journal of the Washington Academy of Sciences Journal 40(9), 277-282.

Williams, A. 1953. North American and European Stropheodontids: their morphology and systematics. The Geological Society of America Memoir 56, 1-67. DOI 10.1130/MEM56-p1

Williams, A. \& Brunton, C.H.C. 1997. Morphological and anatomical terms applied to brachiopods, 423-440. In KAESLER, R.L. (ed.) Treatise on Invertebrate Paleontology, Part H, Brachiopoda (revised), Vol. 1: Introduction. Geological Society of America \& University of Kansas, Boulder \& Lawrence.

Williams, A., Brunton, C.H.C. \& MacKinnon, D.I. 1997. Morphology, 321-422. In KAESLER, R.L. (ed.) Treatise on Invertebrate Paleontology, Part H, Brachiopoda (revised), Vol. 1: Introduction. Geological Society of America \& University of Kansas, Boulder \& Lawrence. 